\title{
DELIVERY OF PHARMACEUTICS TO BONE: NANOTECHNOLOGIES, HIGH- THROUGHPUT PROCESSING AND IN SILICO MATHEMATICAL MODELS
}

\author{
I.S. Alencastre ${ }^{1,2}$, D.M. Sousa ${ }^{1,2}$, C.J. Alves ${ }^{1,2}$, L. Leitão ${ }^{1,2}$, E. Neto ${ }^{1,2,4}$, P. Aguiar ${ }^{1,2}$ and M. Lamghari ${ }^{1,2,3}$ \\ ${ }^{1}$ Instituto de Investigação e Inovação em Saúde, Universidade do Porto (I3S), Portugal \\ ${ }^{2}$ Instituto de Engenharia Biomédica, Universidade do Porto (INEB), Portugal \\ ${ }^{3}$ Instituto de Ciências Biomédicas Abel Salazar, Universidade do Porto (ICBAS), Portugal \\ ${ }^{4}$ Faculdade de Medicina, Universidade do Porto (FMUP), Portugal
}

\begin{abstract}
In the last decade, nanobiotechnology research has emerged as a revolutionising new approach to the $21^{\text {st }}$ century pharmaceutical challenges, offering valuable gains in a vast set of biomedical applications. In the field of bone tissue engineering, a broad range of nanotechnology-based delivery systems have been researched and the most recent developments in high-throughput technology and in silico approaches are creating very high expectations.

This review presents a comprehensive overview of the emergent nanotechnology-based materials, processing techniques and research strategies for the delivery of pharmaceutics to bone including the materials general characteristics and the available drug delivery systems to distribute agents systemically or locally. Complementary to what was stated above, it also reviews the latest highthroughput processing techniques and the existent in silico tools (mathematical and computational models) used to help on the design of delivery systems.
\end{abstract}

Keywords: Bone tissue engineering, targeted drug delivery strategies, biomaterials, high-throughput processing technology, in silico tools, nanotechnology.

\footnotetext{
*Address for correspondence:

Meriem Lamghari

I3S/INEB

Rua Alfredo Allen, 208

4220-135 Porto

Portugal
}

Telephone number: +351220408800

Fax: +351226099157

Email: lamghari@ineb.up.pt

\section{Introduction}

A full list of abbreviations used is given in Table 1 . Presently, medics dealing with skeletal diseases have a wide variety of therapeutic agents at their disposal. Factors such as, antibiotics, anticancer, anti-inflammatory, growth factors, enzymes, antibodies, bioactive proteins, cells and non-viral genes (DNAs and RNAs) are currently being addressed for the treatment of bone diseases (Bose and Tarafder, 2012). Still, most of the currently available clinical therapies have significant drawbacks associated and there is no effective treatment for some of the most common bone disorders such as osteoporosis, osteoarthritis, osteomyelitis, infections, bone cancer and fracture repair (Gu et al., 2013). In most cases, the balance between medication side-effects and treatment efficacy remains a major issue and there is a high demand for delivery vehicles that can provide adequate, sustained and localised presentation of drugs in a time-dependent manner.

The majority of the current drugs are administered orally or parenterally but when administered alone, drugs are usually rapidly cleared from circulation showing very low bioavailability and strong limitations in the efficient delivery to the required site of injury (Gittens et al., 2005; Hirabayashi and Fujisaki, 2003; Takahashi-Nishioka et al., 2008; Uludag, 2002; Zhang et al., 2007). In order to overcome this, large doses must be taken with the consequent increase of the toxicity risk. As an example, most of the current anti-osteoporotic drugs are administered at higher doses to account for pharmacological interactions and expose the patients to adverse effects such as the endometritis, cancer risks and intrauterine haemorrhage on women who underwent prolonged oestrogen therapy (Rossouw et al., 2002). Parathyroid hormone (PTH), a Food and Drug Administration (FDA) approved drug, is recommended to be administered only to severe cases for a maximum period of two years (Tashjian and Goltzman, 2008; Watanabe et al., 2012). Bisphosphonates (BPs) oral therapy has been related with gastritis, gastric ulcer and erosive esophagitis (Graham, 2002; Naniwa et al., 2008). Moreover, as anti-osteoporotic drugs may have to be taken for prolonged times, there is also a problem with patient therapy compliance. Other types of administration such as intravenous, nasal and transdermal delivery have also been addressed. Several drugs such as BPs, PTH and calcitonin can be administered intravenously to avoid first pass effects (Dodson, 2009; Schipper et al., 1994; Shi et al., 2015; Stirling et al., 1991; Tam et al., 1982; Tsavaris et al., 2006) but, because these drugs need to be given on a daily basis, this method of administration is inconvenient 
Table 1. List of abbreviations used in text and tables.

\begin{tabular}{|c|c|}
\hline $3 \mathrm{D}$ & three-dimensional \\
\hline 5TGM1 & mouse myeloma cell line \\
\hline Alen & alendronate \\
\hline alpha-AL-HPLN & $\begin{array}{l}\text { ALCAM-hybrid polymerised liposomal nanopar- } \\
\text { ticle immunoconjugate }\end{array}$ \\
\hline ASCs & adipose-derived stem/stromal progenitor cells \\
\hline AspSerSer(6) & six repetitive sequences of aspartate-serine-serine \\
\hline ATO & arsenic trioxide $\mathrm{As}_{2} \mathrm{O}_{3}$ \\
\hline bFGF & basic fibroblast growth factor \\
\hline BMP & bone morphogenetic protein \\
\hline BPs & bisphosphonates \\
\hline B-TCP & beta tricalcium phosphate \\
\hline $\mathrm{CaP}$ & calcium phosphate \\
\hline $\mathrm{CaPC}$ & calcium phosphate cement \\
\hline $\mathrm{CaS}$ & calcium Sulphate $\mathrm{CaSO}_{4}$ \\
\hline CFS & antibiotic ceftriaxone-sulbactam sodium \\
\hline $\mathrm{CH}$ & chitosan \\
\hline CH-TPP & chitosan-tripolyphosphate \\
\hline $\mathrm{CS}$ & chondroitin sulphate \\
\hline DMOG & dimethyloxaloylglycine \\
\hline DOTAP & dioleoyl trimethylammonium propane \\
\hline Dox & doxycycline \\
\hline DSPC & distearoylphosphatidylcholine \\
\hline ERK1/2 & extracellular signal-regulated kinase \\
\hline EWS & Ewing sarcoma \\
\hline FDA & Food and drug administration \\
\hline FGF & fibroblast growth factor \\
\hline Fli-1 & Friend leukemia integration 1 transcription factor \\
\hline FTY720 & $\begin{array}{l}\text { selective agonist for sphingosine 1-phosphate } \\
\text { receptors }\end{array}$ \\
\hline HA & hyaluronic acid \\
\hline Hap & hydroxyapatite \\
\hline HEK293 & human embryonic kidney cells \\
\hline hMSCs & human mesenchymal stem cells \\
\hline IGF-1 & insulin-like growth factor 1 \\
\hline iPSCs & pluripotent stem cells \\
\hline $\mathrm{LDH}$ & layered double hydroxide \\
\hline Lov & lovastatin \\
\hline MC3T3-E1 & pre-osteoblastic cell line \\
\hline MCF-7 & human breast cancer cell line \\
\hline MBG & mesoporous bioactive glass \\
\hline MG63 & human osteosarcoma \\
\hline $\mathrm{MNU}$ & N-methyl-N-nitrosourea \\
\hline $\mathrm{mPEG}$ & polyethylene glycol monomethyl ether \\
\hline MS & mesoporous silica \\
\hline MTX & methotrexate \\
\hline ND & nanodiamonds \\
\hline NFK $\beta$ & nuclear factor kappa B \\
\hline NO & nitric oxide \\
\hline
\end{tabular}

\begin{tabular}{|c|c|}
\hline NP & nanoparticle \\
\hline NS & nanospheres \\
\hline OPG & osteogenic growth peptide \\
\hline OVX & ovariectomised \\
\hline PAH & poly (allylaminehydrochloride) \\
\hline PC3 & human adenocarcinoma of the prostate \\
\hline PEG & polyethylene glycol \\
\hline PCL & polycaprolactone \\
\hline PCLA & poly ( $\varepsilon$-caprolactone-co-lactide) \\
\hline PEG & polyethylene glycol \\
\hline PEI & polyethylenimine \\
\hline PLA & polylactic acid \\
\hline PLA-DX-PEG & $\begin{array}{l}\text { poly-d 1-lactic acid-p-dioxanone-polyethylene } \\
\text { glycol block co-polymer }\end{array}$ \\
\hline Plekho1 & casein kinase-2 interacting protein-1 \\
\hline PLGA & poly(L-lactide-co-glycolide) \\
\hline PLK 1 & polo-like kinase 1 \\
\hline PLL & poly-L-lysine \\
\hline PLLA & poly-L-lactide \\
\hline PTH & parathyroid hormone \\
\hline PTX & paclitaxel \\
\hline Pur & purmorphamine \\
\hline RA & rheumatoid arthritis \\
\hline RAW 264 & mouse macrophage cancer cell line \\
\hline RANK & receptor activator of nuclear factor $\kappa \mathrm{B}$ \\
\hline RES & reticuloendothelial system \\
\hline rhBMP-2 & $\begin{array}{l}\text { Recombinant human bone morphogenetic pro- } \\
\text { tein-2 }\end{array}$ \\
\hline Ris & risondronate \\
\hline RNA & ribonucleic acid \\
\hline RNAi & RNA interference \\
\hline Ros & rosuvastatin \\
\hline RPMI 8226 & human myeloma cell line \\
\hline Saos-2 & human osteosarcoma cells \\
\hline shRNA & short hairpin RNA \\
\hline Sim & simvastatin \\
\hline siRNA & small interfering RNA \\
\hline SPIONs & superparamagnetic iron oxide nanoparticles \\
\hline Src & proto-oncogene tyrosine-protein kinase \\
\hline SMO & proto-oncogene tyrosine-protein kinase \\
\hline T47D & breast cancer cell line \\
\hline $\mathrm{TCaP}$ & tricalcium phosphate \\
\hline TGF & transforming growth factor \\
\hline TGF ss 1 & transforming growth factor ss 1 \\
\hline $\mathrm{Ti}$ & titanium \\
\hline VCM & vancomycin \\
\hline VEGF & vascular endothelial growth factor \\
\hline Zol & zoledronate \\
\hline
\end{tabular}

and difficult to follow through. Calcitonin is also available as a nasal spray, but the small surface area available and the rapid mucociliary clearance is very limiting (Dodson, 2009; Schipper et al., 1994; Stirling et al., 1991; Tam et al., 1982; Tsavaris et al., 2006). Oestradiol can be delivered transdermally, by application to the skin, but not many drugs possess the physicochemical properties for this type of delivery (Shuid et al., 2013).

Currently, other than seeking new agents, efforts should be made in the development of innovative approaches that enable a specific and targeted delivery of therapeutics to bone and, therefore, improve drug efficiency and patients compliance while minimising adverse side-effects.

Despite having a fairly simple microscopic structure composed of 50-70\% mineral (primarily hydroxyapatite), $20-40 \%$ organic matrix (mainly collagen type I), 5-10\% water and 1-5\% lipids, bone repair/regeneration entails significant challenges due to bone's complex geometries and highly hierarchical and integrated structures, including hard and soft tissues (Ruppel et al., 2008). Such structure, combined with the existence of a membrane of lining cells, which form a marrow-blood barrier and 
prevent the access of large exogenous substances to the bone surface (Travlos, 2006), makes the development of bone-specific delivery systems a difficult task.

Controlled drug delivery systems became available in the early 70s and are now a dynamic field of research (Jeong et al., 2002; Qiu and Park, 2001). The most recent efforts are looking into the development of multifunctional and stimuli-sensitive nanoparticles with well-defined structures/patterns that allow the combined delivery of different therapeutic agents (such as anti-bacterial agents and osteogenesis and angiogenesis stimulators) in response to specific local stimuli (such as temperature, $\mathrm{pH}$, ionic strength, ions, etc.), thus potentiating the therapeutic results (Caldorera-Moore and Peppas, 2009; Tautzenberger et al. 2012; Torchilin, 2014).

To be considered a drug carrier, the material must be non-toxic (i.e. bioinert or biodegradable), biocompatible, able to incorporate a drug either physically or chemically, retain the drug up to the specific target without causing side effects in other cells or tissues, and have the capacity to deliver the drug in a controlled time manner (Bose and Tarafder, 2012).

In the most recent strategies, different types of materials from biologics, polymers, silicon-based materials, carbon-based materials, metals, or combinations of them, structured in nanoscale formats are being considered (Satarkar and Zach Hilt, 2008).

The choice of material depends on the therapeutics chemical characteristics (i.e, hydrophobicity or hydrophilicity, molecular size, isoelectric point, etc.), on the delivery rate intended, on whether materials degradation is desired or not, on the targeted bone, on the targeted cell(s) and on the size of the injury. Complementary, also the carrier's structure, molecular weight, and drug release mode (such as by passive diffusion, carrier degradation, or degradation of a linker that connects the drug and carrier) have major effects on the efficacy of the drug delivery in a context-specific manner. Higher molecular weight carriers present longer circulating half-lives (that putatively potentiate the drug accumulation at the targeted diseased sites) but also an increased uptake by the reticuloendothelial system (RES) (Pan et al., 2008; Wang et al., 2006). Therefore, the carrier's molecular weight, and ultimately its hydrodynamic radius, is a very important factor to take into account in drug delivery systems. Whenever the delivered therapeutics may be degraded by lysosomal enzymes, and does not create biocompatibility issues following RES uptake, high molecular weight and high targeting moieties may be advantageous over smaller ones. On the contrary, in cases where the drug's metabolism by the RES is a concern, lower molecular weight carriers with lower percentages of targeting moieties can be recommended (Low and Kopecek, 2012).

By presenting a similar size to bone ultrastructure, nanoparticles contain great potential as bone-specific carriers. The unique physicochemical properties of nanostructured biomaterials, such as being ultra-small and of controllable size, large surface area to mass ratio, presenting high reactivity and functionalisable structure has been widely explored by pharmaceuticals as means to circumvent some of the limitations of conventional drug delivery methods. In fact, when compared with traditional methods, drug delivery systems using nanoparticles present several advantages: i) circulation time is considerably increased due to the capacity to protect the drug from degradation and avoidance of its renal excretion; ii) drug bioavailability is improved and the solubilisation of lipophilic drugs is enhanced (due to the large surface area); iii) drug release can be performed in a controlled and sustained manner, with the consequent reduction on plasma level fluctuations and side-effects; and vi) drug delivery to specific sites, improving the protection of non-target tissues and cells (Moghimi et al., 2001; Papahadjopoulos et al., 1991; Torchilin, 2005). Moreover, the surface modification of nanoparticles by polyethylene glycol (PEG) chains was shown to increase the circulation time (Klibanov et al., 1990) and is highly explored for the passive delivery of drugs such as the anticancer ones (Gabizon et al., 1994; Matsumura and Maeda, 1986). Still, taking into consideration the above described features of higher molecular weight carriers, depending on the application, macromolecular and small molecule drug delivery should also be considered (Low and Kopecek, 2012).

The drug loading in a carrier may be achieved by many means such as adsorption, incorporation, inclusion and connection through degradable linkers. The use of degradable linkers may be of upmost value for the tuning of the drug release profile. By inducing chemical modifications on the linker, either an immediate administration of high amounts of drug or small amounts of drug administered over an extended period of time may be obtained (Low and Kopecek, 2012). Moreover, by including responsive linkers for bone targeting such as specific enzymes cleavage sites or $\mathrm{pH}$-sensitive sequences, a precise site-specific release of the drug may be achieved (Mullen et al., 2014; Such et al., 2015; Wang et al., 2013). Several studies using sensitive linkers to metalloproteinases (expressed by osteoclasts, osteoblasts and overexpressed in many bone metastasis) (Hu et al., 2011; Liu et al., 2015; Takaishi et al., 2008), cathepsin K (expressed at resorption lacunae) (Segal et al., 2009), cathepsin B (Ogbomo et al., 2013), and acidsensitive linkers (such as hydrazone bonds) (Xu et al., 2015) have been shown to be effective for the drug release at specific cells/sites. In addition, characteristics such as elongated spacers (Miller et al., 2009; Miller et al., 2008; Segal et al., 2009) and disulphide linkers (Kowalczyk et al., 2012; Kurtoglu et al., 2009) have also been considered for drug release into bone.

Presently, the number and complexity of the different therapeutics/biomaterials/technology combinations being investigated for targeted drug delivery in bone is very extensive. Although the effects of many of these systems have been widely approved in animal models, so far only very few have been approved for clinical use (Anderson et al., 2014). Still, considering the large number of in vitro and in vivo preclinical studies currently ongoing this is now a very promising field of research.

Following, we provide an overview of the currently available approaches to drug delivery to bone. The pipeline advancements in computational and high-throughput approaches will be discussed. Cell-based therapies will not be encompassed. 


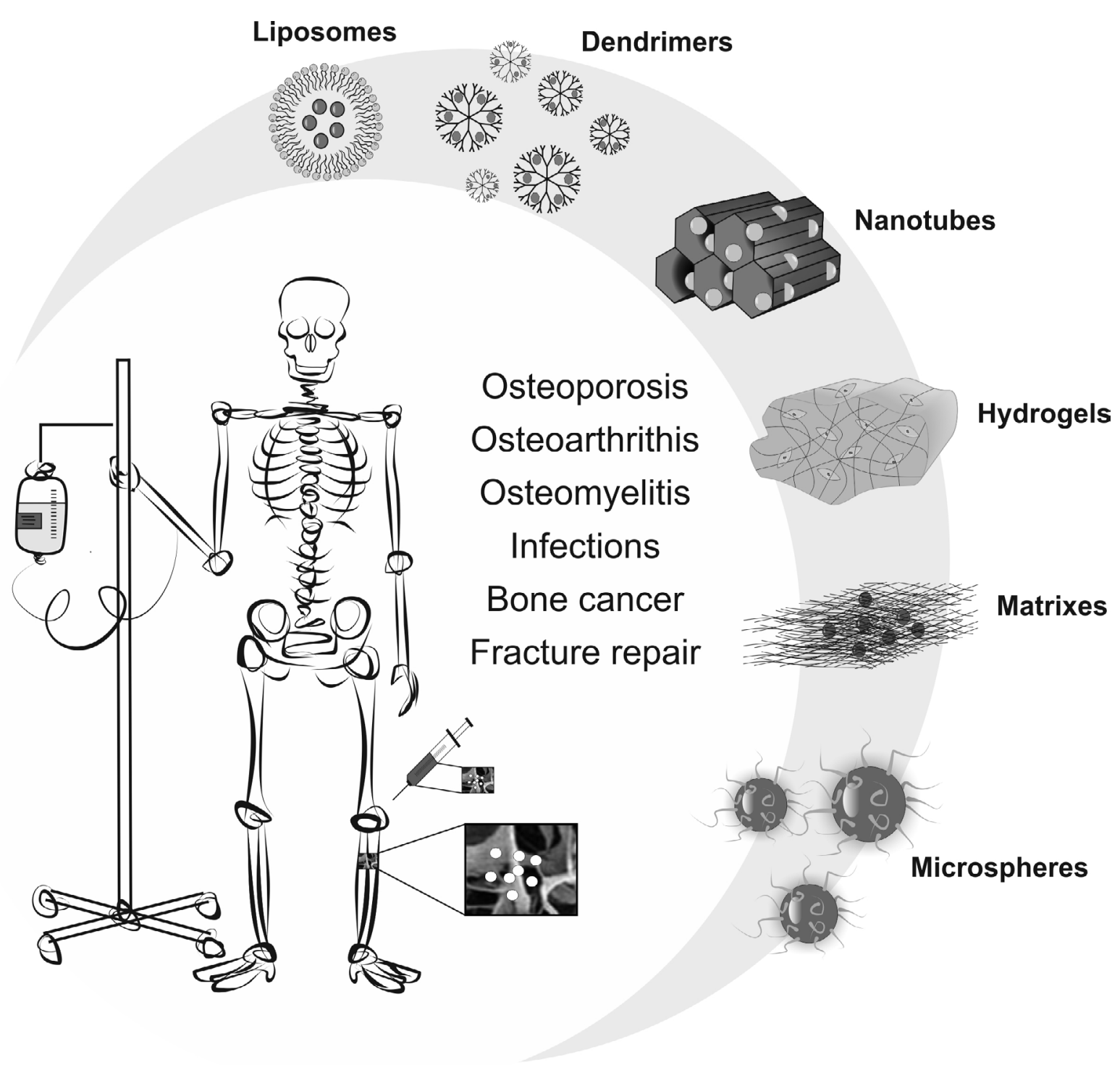

Fig. 1. Schematic overview of the options for targeted drug delivery to bone.

\section{Drug delivery systems to bone}

Systemic bone-related diseases (such as osteoporosis and osteoarthritis) may be better addressed with a systemic delivery system that releases the drug specifically to a broad range of bones in the body. Conversely, a localised injury (such as a critical fracture) may require a local delivery of the therapeutics that can be accomplished either by surgical implantation or by injection of the material at the targeted bone site (Fig. 1).

\section{Systemic drug delivery systems}

Considering the very wide diversity of patients' conditions, bone targeting delivery systems for systemic administration would represent a less invasive route of application, being therefore ideal and more convenient. Drug carriers for systemic drug administration usually enable i) prolonged circulation time in plasma, ii) distribution and accumulation at the targeted tissue and iii) protection of the drug from enzymatic and chemical degradation. Different physical parameters such as particle size (Alexis et al., 2008; Decuzzi et al., 2010; Petros and DeSimone, 2010), shape (Decuzzi et al., 2010; Geng et al., 2007; Tao et al., 2011), rigidity and softness (Merkel et al., 2011) have been shown to affect the particles' pharmacokinetics, targeting ability and cellular uptake. A significant number of researches have been focusing on active and passive targeting of systemically administrated particles to bone.

\section{Oral administration}

Successful oral delivery requires the protection of the drugloaded particles from degradation in the gastrointestinal tract and their safe transportation across the intestinal membrane. The mechanisms of micro- and nanocarriers oral uptake have been extensively investigated. Studies showed that nano- and microparticles are easily taken up by a group of localised endothelial cells in the small intestine, especially by Peyers patch (des Rieux et al., 2006; McClean et al., 1998), with the consequent increase in the drug absorption. In addition, the incorporation of the drug into a particle core can protect it from the gastrointestinal 
tract environment and thus increase the drug stability (Werle et al., 2006) and extend the blood circulation time of the drug (Leane et al., 2004).

Calcitonin and PTH are among the two most explored drugs in oral delivery systems for osteoporosis. Mucoadhesive devices (Gupta et al., 2013; Kawashima et al., 2000) and liposomal formulations (Garcia-Fuentes et al., 2005), poly(L-lactide-co-glycolide) (PLGA) nanoparticles (Sang Yoo and Gwan Park, 2004) and pHsensitive microspheres (Lamprecht et al., 2004) have been tested in vitro and in vivo for the oral delivery of calcitonin, showing enhanced and sustained release of the drug. For the oral administration of PTH, PEGylated and thiolated chitosan nanoparticles loaded with PTH 1-34 showed increased drug half-life and improved bioavailability when compared to the bare peptide that is delivered systemically for treating osteoporosis (Narayanan et al., 2014; Takeuchi et al., 2003). In a different study, PTH 1-34 encapsulated in an oral microemulsion delivery system (85:15, oil/water) consisting of Labrasol, Crodamol GTCC, Solutol ${ }^{\circledR}$ HS 15, d-tocopheryl acetate $(6: 2: 1: 1, w / w)$ and saline water showed high drug loading efficiency $(83 \%)$ and permeability, and significantly higher resistance to proteolysis in vitro. The oral administration to osteoporotic rats showed increased bioavailability and improved bone microstructure (Guo et al., 2011).

Also in the treatment of autoimmune diseases such as rheumatoid arthritis, the use of biodegradable microparticles - first promoted for vaccine development - is now being addressed as an attractive option for an oral administration of auto antigens and inducing of oral tolerance (des Rieux et al., 2006). Kim et al. (2002) showed that a single administration of PLGA nanoparticles entrapping type $\Pi$ collagen could induce oral tolerance more efficiently than repeated oral administrations of intact type $\Pi$ collagen. From the same lab, Lee et al. reported that the conjugation of PEG with immunodominant peptides for collagen-induced arthritis showed promising results as a delivery method for the induction of oral tolerance, rather than the whole Type II collagen and peptide (Lee et al., 2005).

\section{Delivery via the vascular system}

Depending on the final objective, either the mineral portion of the bone (mainly composed of hydroxyapatite) or the bone marrow portion (constituted namely by progenitor cells and lipoproteins) can be targeted.

\section{Targeting bone's mineral fraction}

Systemic delivery of therapeutics to bone can be achieved mainly by enhanced permeability and retention phenomenon, a result of the increased vascular pressure caused by the cytokines present in inflamed tissues or extravasation through vessels in or near the bone (Fang et al., 2011; Maeda, 2010; Maeda et al., 2009; Torchilin, 2011). As bone's vasculature is fenestrated with pore sizes up to $80 \mathrm{~nm}$ (Howlett et al., 1984) (exceeding the hydrodynamic size of most circulating nanomedicines), the targeting of hydroxyapatite by bone-seeking agents offers great possibilities.
Diverse compounds such as BPs, tetracyclines, acidic oligopeptides, and oestradiol analogues have been used to target bone diseases. These compounds have the capacity to bind hydroxyapatite differentially, depending on the crystal size and intrinsic molecule modifications. As the hydroxyapatite crystal structure or exposure is disease specific (for instance, hydroxyapatite crystals in a bone tumour are different from the crystals exposed in a bone fracture), precise targeting can be achieved by using targeting molecules with selectivity for different disease states (Low and Kopecek, 2012). The binding rate of acidic oligopeptides to hydroxyapatite is faster than that of BPs but BPs have a superior binding strength and specificity for hydroxyapatite (Murphy et al., 2007). BPs have the capacity to bind to all bone, while aspartate (Asp8, a common bone-targeting acidic oligopeptide) binds preferentially to higher crystalline hydroxyapatite, characteristic of resorption surfaces (Wang et al., 2006). Meanwhile, tetracycline deposits preferentially onto low crystallinity hydroxyapatite that is mainly present in growing surfaces (Miller et al., 2008). Altogether, when considering approaching bone mass indirectly by means of targeting the main cells responsible for bone formation (osteoblasts) and resorption (osteoclasts), osteoclasts are better targeted with acidic oligopeptides, and osteoblasts with tetracycline (Low and Kopecek, 2012). BPs, such as alendronate (Alen), are distributed to both bone-formation and bone-resorption surfaces (Wang et al., 2006). More recently, (AspSerSer) 6 was found to be a targeting moiety in vivo for bone-formation surfaces (Zhang et al., 2012a), constituting an alternative to tetracycline that presents several side effects such as teeth staining and inhibition of skeletal growth in children (Demers et al., 1968; Vennila et al., 2014). Several preclinical studies considering different bone diseases have tested the potential of bone-seeking agents in conjugation with nanomedicines to be used as drug delivery systems to bone (Hirabayashi and Fujisaki, 2003).

BPs are the most used bone-seeking agent in preclinical research. Different studies comprising BPs' conjugation to small molecules (Hirabayashi et al., 2001a; Hirabayashi et al., 2001b), linear macromolecular carriers (Wang et al., 2005), proteins (Gittens et al., 2005) or nanoparticles (de Miguel et al., 2014; Park et al., 2003; Ross and Roeder, 2011) have been performed (Hirabayashi and Fujisaki, 2003). BP-mediated bone targeting showed promising results in improving and prolonging the drug effects in different bone diseases approaches such as: prostaglandins (Gil et al., 1999), oestradiol (Bauss et al., 1996; Fujisaki et al., 1997; Fujisaki et al., 1998), synthetic estrogenic agents (Tsushima et al., 2000) and nitric oxide (NO) (Lazzarato et al., 2005; Nichols et al., 2012; Zhang et al., 2007) in osteoporosis; nonsteroidal anti-inflammatory drugs (Hirabayashi et al., 2001b) in osteoarthritis; fluoroquinolones (Herczegh et al., 2002) in chronic infections treatment; and cisplastin (Klenner et al., 1990a); melphalan (Klenner et al., 1990b), and methotrexate (Hosain et al., 1996; Yang et al., 2014) for the treatment of bone metastatic cancer. For further examples please see Table 2. Tetracycline and acidic oligopeptides have been 
Table 2. Delivery of BP-conjugated drugs for bone diseases.

\begin{tabular}{|c|c|c|c|c|}
\hline Therapeutic agent & Model of study & Delivery & Efficacy $^{\text {(a) }}$ & Reference \\
\hline \multicolumn{5}{|l|}{ Osteoporosis } \\
\hline prostaglandin E2 & in vivo, OVX rat & intravenous & $\begin{array}{l}\text { More effective in bone growth } \\
\text { stimulant }\end{array}$ & Gil et al., 1999 \\
\hline \multirow[t]{3}{*}{17 beta-Estradiol } & in vivo, OVX rat & subcutaneous & $\begin{array}{l}\text { Similar effect in bone loss } \\
\text { prevention }\end{array}$ & Bauss et al., 1996 \\
\hline & in vivo, OVX rat & intravenous & $\begin{array}{l}\text { Increased bone distribution } \\
\text { and half life }\end{array}$ & Fujisaki et al., 1997 \\
\hline & in vivo, OVX rat & intravenous & Reduction of side-effects & Fujisaki et al., 1998 \\
\hline PTH & in vitro, MC3T3-E1 cells & --- & Increased bioactivity & Yewle et al., 2013 \\
\hline calcitonin & $\begin{array}{l}\text { in vitro, T47D cells } \\
\text { in vivo, OVX rat }\end{array}$ & $\begin{array}{l}--- \\
\text { subcutaneous }\end{array}$ & $\begin{array}{l}\text { Greater affinity and specific- } \\
\text { ity for bone mineral. } \\
\text { Improved efficacy in preserv- } \\
\text { ing bone volume, bone mass } \\
\text { density and trabecular micro- } \\
\text { architecture }\end{array}$ & Bhandari et al., 2010 \\
\hline oestrogen (SM-16896) & in vivo, OVX rat & subcutaneous & $\begin{array}{l}\text { Decreased efficiency in bone } \\
\text { mass effect but reduction of } \\
\text { side-effects }\end{array}$ & Tsushima et al., 2000 \\
\hline nitric oxide & in vivo, rat & intravenous & $\begin{array}{l}\text { Preferential accumulation in } \\
\text { bone. Inhibition of the differ- } \\
\text { entiation of pre-osteoclasts to } \\
\text { functional osteoclasts. }\end{array}$ & Lazzarato et al., 2005 \\
\hline \multicolumn{5}{|l|}{ Osteoarthritis } \\
\hline diclofenac & in vivo, osteoarthritic rat & intravenous & $\begin{array}{l}\text { Increased efficacy end reduc- } \\
\text { tion of side effects }\end{array}$ & Hirabayashi et al., 2001b \\
\hline osteoprotegerin & in vivo, osteoarthritic rat & intravenous & $\begin{array}{l}2 \text { and 4-fold increase in drug } \\
\text { uptake }\end{array}$ & Doschak et al., 2009 \\
\hline \multicolumn{5}{|l|}{ Chronic infections } \\
\hline fluoroquinolones & $\begin{array}{l}\text { in vitro, measurement of } \\
\text { anti-bacterial activity; } \\
\text { ex vivo, bone powder }\end{array}$ & --- & $\begin{array}{l}\text { Improved anti-bacterial ac- } \\
\text { tivity }\end{array}$ & Herczegh et al., 2002 \\
\hline \multicolumn{5}{|l|}{ Cancer } \\
\hline cisplatin & $\begin{array}{l}\text { in vivo, osteosarcoma rat } \\
\text { model }\end{array}$ & intravenous & $\begin{array}{l}\text { Increased anti-tumour ac- } \\
\text { tivity }\end{array}$ & Klenner et al., 1990a \\
\hline \multirow[t]{2}{*}{ taxanes } & $\begin{array}{l}\text { in vivo, breast cancer bone } \\
\text { metastasis mouse model }\end{array}$ & intravenous & $\begin{array}{l}\text { Enhanced anti-tumour ef- } \\
\text { ficacy }\end{array}$ & Miller et al., 2011 \\
\hline & $\begin{array}{l}\text { in vitro, RAW } 264 \text { and } \\
\text { MCF-7 cell lines } \\
\text { in vivo, mice with Ehrlich } \\
\text { ascites tumour in bone }\end{array}$ & intravenous & $\begin{array}{l}\text { Increased anti-tumour ac- } \\
\text { tivity }\end{array}$ & Chaudhari et al., 2012 \\
\hline gemcitabine & in vivo, mice & intravenous & $\begin{array}{l}\text { Increased binding affinity to } \\
\text { hydroxyapatite and bone }\end{array}$ & El-Mabhouh et al., 2006 \\
\hline doxorubicin & in vitro, cow's bone & --- & $\begin{array}{l}\text { A high binding affinity to } \\
\text { hydroxyapatite was exhibited } \\
\text { in vitro. }\end{array}$ & Hochdorffer et al., 2012 \\
\hline \multirow[t]{2}{*}{ proteasome inhibitors } & $\begin{array}{l}\text { in vitro, } 5 \text { TGM } 1 \text { and RPMI } \\
8226 \text { cell lines }\end{array}$ & --- & $\begin{array}{l}\text { Dose dependent cytotoxicity } \\
\text { and decrease of the viable } \\
\text { cells number }\end{array}$ & Agyin et al., 2013 \\
\hline & \begin{tabular}{|l|} 
in vitro, myeloma cells \\
in vivo, mouse models of \\
multiple myeloma \\
\end{tabular} & --- & Inhibition of myeloma growth & Swami et al., 2014 \\
\hline arabinocytidine & $\begin{array}{l}\text { in vivo, mouse models of } \\
\text { tumour-induced bone dis- } \\
\text { ease and multiple myeloma }\end{array}$ & intravenous & $\begin{array}{l}\text { Reduction in the incidence of } \\
\text { bone metastases and overall } \\
\text { tumour burden }\end{array}$ & Reinholz et al., 2010 \\
\hline TNP-470 & $\begin{array}{l}\text { in vivo, K7M2 murine osteo- } \\
\text { sarcoma model }\end{array}$ & subcutaneous & $\begin{array}{l}\text { Increased anti-tumour activ- } \\
\text { ity and lower cytotoxicity }\end{array}$ & Segal et al., 2011 \\
\hline melphalan & $\begin{array}{l}\text { in vivo, rat Walker carcino- } \\
\text { sarcoma model combined } \\
\text { with MNU induced mam- } \\
\text { mary carcinoma }\end{array}$ & intravenous & $\begin{array}{l}\text { Improved anti-carcinogenic } \\
\text { activity }\end{array}$ & Wingen et al., 1988 \\
\hline \multirow[t]{2}{*}{ methotrexate } & in vivo, rabbits & intravenous & $\begin{array}{l}\text { Improved targeted delivery } \\
\text { to bone }\end{array}$ & Hosain et al., 1996 \\
\hline & $\begin{array}{l}\text { in vitro, MG-63 human os- } \\
\text { teosarcoma cell line }\end{array}$ & --- & $\begin{array}{l}\text { Weaker effect in the inhibi- } \\
\text { tion of osteosarcoma cell } \\
\text { proliferation. }\end{array}$ & Yang et al., 2014 \\
\hline
\end{tabular}

(a) In comparison with non-conjugated drugs

Abbreviations are listed in Table 1. 
used for oestradiol delivery in oedema and cancer treatment (Hirabayashi and Fujisaki, 2003) while (AspSerSer) 6 has been used in miRNA delivery for osteoporosis treatment (Ray, 2012; Zhang et al., 2012a).

Concerning gene therapy, an increasing number of molecular targets and nanotechnology-based strategies are being explored (Wang and Grainger, 2012). The delivery of plasmid DNA using chitosan-based nanoparticles (Corsi et al., 2003; Lu et al., 2011; Zhang et al., 2006) and cationic polymers (Ohashi et al., 2001) has showed promising results for the treatment of joint diseases and osteosarcoma.

Alternatively, the popular RNA interference (RNAi)based therapy using small interfering RNA (siRNA) is also exhibiting great potential both ex vivo and in vivo, to regulate progenitor cell differentiation pathways involved in osteogenic cell production for bone regeneration (Benoit and Boutin, 2012). In this regard, considering the very low cellular penetration of siRNA (consequence of its large size and anionic nature) vectors that can provide a safe and efficient gene transfer are being extensively researched. Systemic targeted-delivery strategies usually resort to known bone-homing chemistry to bind mineralised phases of inorganic bone such as the FDA approved for clinical trials, dioleoyl trimethylammonium propane-based liposomes conjugated with the targeting oligopeptide peptide (AspSerSer) ${ }_{6}$ (Zhang et al., 2012a). In bone repair, several gene silencing such as Noggin (Manaka et al., 2011), receptor activator of nuclear factor $\kappa \mathrm{B}$ (RANK) (Wang et al., 2012), NFк $\beta$ (Yao et al., 2009); Src (Zheng et al., 2015); osteopontin and osteocalcin (Zhang et al., 2010), have been explored as a mean to regulate bone formation and mineralisation. As an example, polylactide (PLA)-polydioxanone-PEG copolymer hydrogels loaded with Noggin siRNA and bone morphogenetic protein (BMP-2) implanted into mouse dorsal pouches resulted in the stimulation of ectopic bone formation, with higher bone mineral content and greater bone quantity than that observed by delivery of an equivalent dose of BMP-2 alone (Manaka et al., 2011). Layer by layer film composed of alternating layers of calcium phosphateshRNA nanoparticles and PLL presented a sustained silencing effect for $21 \mathrm{~d}$ in human osteoblasts grown on the films (Zhang et al., 2010). For Ewing's sarcoma (EWS), diamond nanoparticles coated with cationic polymer (nanodiamonds, NDs) have successfully been used to deliver siRNA into EWS cells where they achieved specific inhibition of EWS/Fli-1 gene expression at the mRNA and protein levels showing therefore promising data for tumour treatment (Alhaddad et al., 2011; Toub et al., 2006). In a different study, a polymer carrier for the delivery of siRNA to silence two distinct pathways, the PLK1 pathway for osteosarcoma cancer cells and the ERK1/2 pathway in osteoarthritis, as has been shown to slow down the progress of the diseases (Truong et al., 2013).

In cell therapeutics, nanotechnology has been mainly explored for cell labelling procedures. Quantum dots, superparamagnetic and gold nanoparticles-cell labelling during regenerative therapies has been efficiently used for the visualisation and tracking of the cell transport to the area of the defect in vivo, and for the assessment of the fate and participation of the transplanted cells in tissue regeneration. Pluripotent stem cells (iPSCs), mesenchymal stem cells (MSCs) and adipocyte-derived stem/stromal progenitor cells (ASCs), are currently under extensive investigation using tissue engineering strategies for bone regeneration applications (Tautzenberger et al., 2012; Vo et al., 2012), namely in combination with siRNA delivery, but such approaches will not be encompassed in this review.

\section{Targeting bone marrow cells}

Together with its functions in haematopoiesis and in the immune system, bone marrow cells have also been implicated in many bone disorders such as rheumatoid arthritis, bone regeneration and repair, bone metastases and osteoporosis (Delaisse, 2014), constituting therefore a relevant target for potential therapies (Table 2).

The traditional drug delivery to bone marrow relied on uncontrolled passive diffusion through blood circulation. This is a highly ineffective method, with only a very small fraction of drugs reaching the target site. Therefore, the development of bone marrow-targeted drug delivery carriers offers great potential to the development of more efficient diagnostic and therapeutic systems. Both in vitro and in vivo tests using liposomes, polymers, microspheres, nanoparticles, silicon particles, and polypeptides as drug carriers have showed efficient targeting of bone marrow cells (Harris et al., 2010; Luhmann et al., 2012; Mann et al., 2011; Porter et al., 1992; Schettini et al., 2006; Sou et al., 2010; Sou et al., 2011). In a study by Chi et al. (2010) dendritic amine and guanidinium group-modified nanoparticles were investigated for the delivery of model peptide drug into primary osteoclast precursor cells showing a significant cellular uptake of the nanoparticles (Chi et al., 2010). (Porter et al., 1992) showed that polystyrene particles coated with the block copolymer poloxamer-407, a non-ionic surfactant, would selectively redirect intravenously injected microspheres to sinusoidal endothelial-cells of rabbit bone-marrow (Porter et al., 1992). Particles of $150 \mathrm{~nm}$ in diameter and below evaded recognition by Kupffer cells and efficiently accumulated in sinusoidal endothelial cells of rabbit bone marrow (Porter et al., 1992). Importantly, no marked uptake was achievable with other block co-polymers having a similar structure to that of poloxamer-407, suggesting the participation of a specific interaction mechanism between the particle and the sinusoidal endothelial cell surface. After several years, the concept of active targeting to bone marrow endothelial cells was recently recharged. In a study by Chi and co-workers, dendritic amine and guanidinium group-modified nanoparticles were investigated for the delivery of model peptide drug into primary osteoclast precursor cells showing a significant cellular uptake of the nanoparticles (Chi et al., 2010). Harris et al. prepared cationic nanoparticles with plasmid DNA and then coated their cationic surface with poly(anionic)poly(glutamic acid)-based peptides, with and without cationic insert, and showed that the terminal sequence insert, cationic amino acid sequence G-dP-dL-G-dV-dR-G, to the poly(glutamic acid)-based peptides is a critical factor for enhancing bone marrow and spleen-specificity of gene delivery in vivo (Harris et al., 2010). 
Based on the evidence that E-selectin, expressed on normal endothelial cells in response to inflammatory stimuli, is constitutively expressed in bone marrow endothelium and is involved in leukemic cell homing (Sipkins et al., 2005), Mann and co-workers developed porous silicon particles modified with E-selectin thioaptamer ligands to target bone marrow endothelium (Mann et al., 2011). Studies on mice demonstrated an 8 -fold increase on the accumulation of porous silicon particles modified with E-selectin compared to control porous silicon particles, which were accumulated primarily in the liver and spleen instead of bone marrow (Mann et al., 2011).

The microvascular bed in cortical bone consists of endothelial cells with no phago-endocytotic activity nor fenestration, and restricts the passive transvascular transport of macromolecules to particles that are able to pass $\sim 5 \mathrm{~nm}$ pores within the endothelium. In contrast, sinusoidal blood capillaries in bone marrow are characterised by diaphragmed fenestrae and phagoendocytotic activity of endothelial cells (Sarin, 2010). Systemically administered particles may permeate sinusoidal endothelium and be sequestered into bone marrow, which has been explored for bone marrow imaging using radiolabelled albumin microspheres and microaggregates $(10-30 \mathrm{~nm})$ and polyvinylpyrrolidone nanoparticles (1-13 nm) (Moghimi et al., 1990). Liposomes consisting of distearoylphosphatidylcholine (DSPC), cholesterol, PEG(5000)-DSPE, and $\alpha$-tocopherol prepared in various sizes (136-318 nm diameter) have been tested for organ distribution in rabbits but none of these liposomes showed a significant accumulation in bone marrow (Awasthi et al., 2003).

Overall, active and passive targeting of systemically administered particles to the bone marrow remains a challenging task. Presently, the active targeting of particles through the sinusoidal epithelia of bone marrow is a promising approach to targeted deposition of delivery systems in the bone marrow. Most studies suggested a predominant role of specific targeting over particle size for accumulation in bone marrow, but systematic studies are still required.

\section{Local drug delivery systems}

Although implicating a more invasive approach, the local delivery of drugs, entails some advantages over the systemic delivery: i) the drug quantity necessary is reduced, ii) unwanted side effects on other cells or organs/ tissues is minimised, iii) drugs are retained and kept in the local for increased periods, increasing the treatment time and efficacy and iv) the adequate tuning of the delivery system allows a time-controlled delivery according to the requirements.

Ideally, local drug delivery system to bone should be designed to deliver the drug through minimally invasive procedures, such as by injection to the local site, and possess the ability for in situ matrix formation. In this way, wound healing would be significantly accelerated, requirements of irregular shape defects are more easily met and patients comfort and compliance is increased $(\mathrm{Xu}$ et al., 2008; Yasmeen et al., 2014). Moreover, materials should be biodegradable, able to uptake large quantities of drug, retain the drug at the desired site and release the drug slowly to the bone and surrounding tissue.

Delivery systems for the local drug release are the most investigated approach in bone therapeutics and the design options are virtually unlimited. Still, for clinical applications novel injectable biomaterials with improved properties such as mechanical strength, biocompatibility, and vascularisation are necessary.

The most investigated drugs in local drug delivery systems to bone are anti-cancer drugs, BPs and growth factors. Numerous organic, inorganic and combined systems are available for the local drug delivery into bone. Organic nanoparticles include lipids, dendrimers, chitosan, carbon nanotubes (Moore et al., 2013), nanoparticles such as poly-L-lysine (PLL), PLA, polyglycolic acid, polycaprolactone (PCL) or copolymers of these such as PLGA. The inorganic nanoparticles are usually composed of silica, hydroxyapatite, or metals such as gold, silver and iron (Tautzenberger et al., 2012). In Table 3 we present exemplary studies on different materials used in local delivery of therapeutics to bone.

Depending on their interaction with the host tissue, materials can be divided in bioinert and bioactive. It is now clear that besides the composite, the inherent nanostructure, namely the hierarchical porous structure, plays a major role the bioactivity level of bioactive materials. For this reason, in the past decade, synthesis and application of mesoporous solids, with highly ordered structures, high surface area and large pore volume have been significantly investigated for the encapsulation of pharmaceutical therapeutics (Vallet-Regi et al., 2012). This material has showed excellent performance in both controlled drug delivery with sustained release profiles and formulation of poorly aqueous soluble drugs with enhanced bioavailability (Shen et al., 2013). With the preparation of the first mesoporous bioactive glasses (MBG) in 2004 by Yan et al., (Yan et al., 2006; Yan et al., 2004), the combination of drug delivery with bioactive materials was achieved, starting a new model for improved bone regeneration applications by the functional effect of nanomaterials. These materials are based on a $\mathrm{CaO}-\mathrm{SiO}_{2}-\mathrm{P}_{2} \mathrm{O}_{5}$ composition and have a highly ordered mesopore channel structure with a pore size ranging from 5-20 $\mathrm{nm}$. Compared to conventional non-MBGs, the MBGs have improved surface area, pore volume, ability to induce in vitro apatite mineralisation in simulated body fluids, and excellent cytocompatibility (Alcaide et al., 2010; Li et al., 2007a; Wu et al., 2014; Yan et al., 2006). Moreover, MBG 3D porous scaffolds can be prepared by high-throughput techniques and can, therefore, yield a highly controlled material structure to be used in bone tissue engineering and drug delivery applications (Wu and Chang, 2012). Different studies have reported an efficient therapeutics delivery to bone by means of MBG scaffolds (Wu and Chang, 2012; Wu et al., 2013; Wu et al., 2011).

Functional ions, such as Li, Sr, Co and B; small molecular drugs like dexamethasone, dimethyloxaloylglycine (DMOG), and gentamicin; and growth factors such as vascular endothelial growth factor (VEGF) and BMP loaded into MBG scaffolds showed great potential as a release 
Table 3. Exemplary studies on different materials used in local delivery of therapeutics to bone.

\begin{tabular}{|c|c|c|c|c|c|}
\hline & Therapeutic agent & Delivery & Therapeutic indication & Model of study & References \\
\hline \multicolumn{6}{|l|}{ Inorganic } \\
\hline $\begin{array}{l}\text { MS and MS/apatite } \\
\text { nanoparticles }\end{array}$ & OPG & Implant & Bone regeneration & In vitro; Simulated body fluid & Mendes et al., 2013 \\
\hline CaP nanocapsules & Sim & Injection & Osteoporosis & In vivo; Ovariectomised mouse & Ito et al., 2013 \\
\hline HAp & Pur & Implant & Fracture & In vivo; Foetal chick femur & Gellynck et al., 2013 \\
\hline $\mathrm{CaP}$ cement & Alen & Implant & Osteoporosis & In vitro & Jindong et al., 2010 \\
\hline Nanodiamonds & BMP-2; bFGF & Injection & Bone formation & $\begin{array}{l}\text { In vitro, Osteoblast progenitor } \\
\text { cells }\end{array}$ & Moore et al., 2013 \\
\hline $\mathrm{CaP}$ & Zol & Injection & Osteoporosis & $\begin{array}{l}\text { In vivo, Ovariectomised rat and } \\
\text { sheep }\end{array}$ & Verron et al., 2010 \\
\hline $\mathrm{CaS}$ & Sim & Implant & Fracture & In vivo, Rat tíbia osteotomy & Qi et al., 2013 \\
\hline 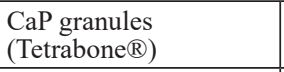 & \begin{tabular}{|l|}
$\begin{array}{l}\text { Helioxanthin ago- } \\
\text { nist }\end{array}$ \\
\end{tabular} & Implant & Fracture & In vivo, Rat Femur bone defect & Maeda et al., 2013 \\
\hline LDH nanocarriers & MTX & - & Osteosarcoma & In vitro, Saos- 2 cell culture & Oh et al., 2011 \\
\hline $\mathrm{Ti}$ & BMP-2 & Implant & Fracture & In vivo, Rat tibial defect & Ishibe et al., 2009 \\
\hline \multicolumn{6}{|l|}{ Organic } \\
\hline Collagen & Ros & Implant & Fracture & $\begin{array}{l}\text { In vivo, Critical-size rabbit } \\
\text { bone defect }\end{array}$ & Monjo et al., 2010 \\
\hline $\begin{array}{l}\text { Collagen sponge- } \\
\text { Teraplug } \AA\end{array}$ & $\mathrm{N}$-acetyl cysteine & Implant & Fracture & $\begin{array}{l}\text { In vivo, Critical-size rat femur } \\
\text { bone defect }\end{array}$ & Yamada et al., 2013 \\
\hline Gelatine hydrogels & rhBMP-2 & Implant & Bone formation & In vivo, mouse subcutaneous & Kimura et al., 2010 \\
\hline PLGA & FTY720 & Implant & Allograft implants & $\begin{array}{l}\text { In vivo, Critical-size rat tibia } \\
\text { defect }\end{array}$ & Petrie Aronin et al., 2010 \\
\hline $\begin{array}{l}\text { PLGA/PLLA nano- } \\
\text { fibrous scaffolds }\end{array}$ & Dox & Implant & Periodontitis and RA & In vitro, antibacterial assays & Feng et al., 2010 \\
\hline PLA-Nanospheres & BMP-2 & - & Fracture & $\begin{array}{l}\text { In vitro, microculture } \\
\text { tetrazolium test }\end{array}$ & Chen et al., 2011a \\
\hline Polyurethane scaffolds & Los & Implant & Fracture & $\begin{array}{l}\text { In vivo, critical-sized rat femur } \\
\text { bone defect }\end{array}$ & Yoshii et al., 2014 \\
\hline \multicolumn{6}{|l|}{ Organic-Inorganic } \\
\hline $\begin{array}{l}\text { PLGA-MS membranes } \\
\text { (SBA15) }\end{array}$ & rhBMP-2 & Implant & Bone tissue engineering & $\begin{array}{l}\text { In vitro, human bone marrow- } \\
\text { derived mesenchymal stem } \\
\text { cells }\end{array}$ & Zhou et al., 2014 \\
\hline B-TCaP / Collagen & FGF-2 & Injectable & Fracture & $\begin{array}{l}\text { In vivo, rabbit tibia segmental } \\
\text { defect }\end{array}$ & (Komaki et al., 2006) \\
\hline $\begin{array}{l}\text { CaP/Gelatine micropar- } \\
\text { ticles }\end{array}$ & TGF-ss 1 & Injectable & Fracture & $\begin{array}{l}\text { In vivo, Rabbit femoral bone } \\
\text { defect }\end{array}$ & Link et al., 2008 \\
\hline $\begin{array}{l}\text { HAp plasma-coated } \mathrm{Ti} \\
\text { alloy cylinders }\end{array}$ & Zol & Implant & $\begin{array}{l}\text { Implant fixation in } \\
\text { osteoporotic bone }\end{array}$ & $\begin{array}{l}\text { In vivo } \\
\text { Ovariectomized sheep }\end{array}$ & Stadelmann et al., 2008 \\
\hline $\begin{array}{l}\text { PLGA/HAp micro- } \\
\text { spheres }\end{array}$ & Sim & - & $\begin{array}{l}\text { Osteonecrosis bone } \\
\text { defects }\end{array}$ & $\begin{array}{l}\text { In vivo, mouse model of gap } \\
\text { fracture bridging with a graft of } \\
\text { necrotic bone }\end{array}$ & Tai et al., 2013 \\
\hline $\begin{array}{l}\text { 3D apatite-coated } \mathrm{CH} / \\
\text { CS scaffold }\end{array}$ & BMP-2, ASCs & Implant & Bone defects & $\begin{array}{l}\text { In vivo, rat critical-sized } \\
\text { mandibular defect model. }\end{array}$ & Fan et al., 2014 \\
\hline
\end{tabular}

Abbreviations are listed in Table 1.

system to enhance osteogenesis, angiogenesis and antibacterial/cancer activity (Wu et al., 2014). Li, $\mathrm{Sr}, \mathrm{Mg}, \mathrm{Cu}$, $\mathrm{Fe}, \mathrm{B}$ and $\mathrm{Zr}$ presented a positive effect on osteogenesis. $\mathrm{Cu}$ and $\mathrm{Co}$ ions were shown to stimulate angiogenesis and $\mathrm{Ag}$ and $\mathrm{Cu}$ ions showed anti-bacterial activity. The combined release of $\mathrm{Si}$ ions with $\mathrm{Li}, \mathrm{Sr}, \mathrm{Cu}$ displayed a synergistic effect and a further enhancement of the osteogenesis and angiogenesis. The delivery of therapeutic drugs and growth factors, such as Dexamethasone, DMOG, BMP and basic fibroblast growth factor (bFGF) from MBG, significantly promoted in vitro and in vivo osteogenesis. DMOG and VEGF release showed an increase of angiogenesis. Gentamicin and ampicillin delivery inhibited the bacterial activity and doxorubicin presented anti-cancer effect ( $\mathrm{Wu}$ et al., 2014).
Although nanoparticles alone can provide sustained and even sequential release in vitro (Chen et al., 2011a; Yilgor et al., 2010) in bone tissue engineering applications, their incorporation into a scaffold or hydrogel matrix creates additional control over the kinetic properties, increasing treatment efficacy and specificity for improved bone repair (Isikli et al., 2012; Nandagiri et al., 2011). Most frequently, nanoparticles are combined with scaffolds such as solid implants, hydrogels or degradable polymeric matrixes, which can be stimulus responsive or have preprogrammed release kinetics to deliver bioactive molecules in a localised, spatiotemporal manner in agreement with the natural wound healing process. Complementary to this, the scaffold should provide support for cell migration, proliferation, synthesis extracellular matrix 
and establishment of vascular networks. Properties such as injectability and in situ forming gels have also been highly explored in order to minimise surgical procedures (Yasmeen et al., 2014). Again, a large variety of inorganic, natural, and synthetic materials have been used for the generation of controlled system scaffolds (Vo et al., 2012).

\section{Hydrogels}

Hydrogels are among the most studied materials for the development of novel delivery systems for bone regeneration by combining a good biocompatibility with the capacity to provide the controlled release of functional therapeutics and a tissue-compatible substrate for cell attachment and growth, simulating an artificial extracellular matrix (Vo et al., 2012).

They are a class of hydrophilic, crosslinked polymeric networks, insoluble in water that possess the ability to hold large amounts of fluids within its structure: Very different experimental settings ranging from different materials sources to the cross-linking degree, the drug-loading and release mode are being, explored with the purpose of drug delivery to bone. The most explored therapies concern protein, antibiotics and cell delivery. Both synthetic materials, such as PEG-based polymers (Lin and Anseth, 2009; Milleret et al., 2014), and natural polymers like gelatine (Young et al., 2005), alginate (Kolambkar et al., 2011; Miao et al., 2014; Rubert et al., 2013), fibrin (Hong et al., 2014; Yang et al., 2010), and hyaluronic acid (Kim et al., 2007) are being considered. Studies in a rabbit segmental defect and mouse subcutaneous implantation model propose an optimum hydrogel water content and crosslinking density for synchronised delivery and bone formation (Kimura et al., 2010; Yamamoto et al., 2006). Moreover, "stimuli-responsive" or "smart" hydrogels, with the capacity to respond to external stimuli, such as $\mathrm{pH}$, temperature or electric stimuli are being developed (Basak et al., 2014; Sood et al., 2014) creating exciting new opportunities for controlled drug delivery.

Still, among their characteristics, hydrogels also possess weak mechanical properties and low bioactivity (Shaikh et al., 2010) and the most recent strategies in this field are focusing in the combination of hydrogels with nanofillers, such as carbon nanotubes in a way to surpass such setbacks (Cirillo et al., 2014; Yasmeen et al., 2014). The development of injectable, stimuli-responsive gels containing hydroxyapatite and carbon nanotubes as nanofillers are among the latest approach in hydrogels delivery systems to bone (Yasmeen et al., 2014).

\section{Stimulus responsive}

In recent years, biomaterials research as advanced from the investigation of biocompatible and biodegradable materials to the design of stimuli-responsive biomaterials that can respond to a variety of stimuli, including selective physical (e.g., temperature), chemical (e.g., $\mathrm{pH}$ and ionic strength) and biomolecular recognition (e.g., enzyme, peptide- and lipid-based interactions) stimuli (Lu et al., 2014). Some of these stimuli, like the $\mathrm{pH}$ in different cellular compartments or disease states, occur naturally in vivo, while others, such as light and ultrasounds, are externally controlled allowing the external temporal and spatial control of the release (Fleige et al., 2012).

Considering the fact that bone repair entails a combination of sequential and cooperative signalling events in response to changes in their microenvironment the incorporation of stimulus-responsive elements into therapeutics delivery vehicles allows for improved biomimetic strategies.

Temperature and $\mathrm{pH}$-sensitive polymers are among the most studied stimulus-responsive materials, mainly in combination, to form dual-responsive delivery systems. Temperature-sensitive polymers generally show low critical solution temperature behaviour, where if a certain temperature threshold is surpassed the polymer undergoes a reversible phase transition that can be exploited for drug release. By varying the hydrophilic or hydrophobic co-monomer content the low critical solution temperature can be tuned to create the desired temperature transition (Shaikh et al., 2010). pH responsive polymers result from the presence of weakly acidic (e.g., carboxylic and sulphonic acids) and/or weakly basic (e.g., ammonium salts) functional groups on the polymeric backbone, which allow for reversible swelling/de-swelling behaviour in acidic or basic media (Shaikh et al., 2010). Poly(Nisopropylacrylamide) (Garbern et al., 2010; Na et al., 2007), poly(organophosphazenes) (Chun et al., 2009), PEG-based di/tri block copolymers (He et al., 2008), PCL (Kim et al., 2006) and their derivatives as well as biomimetic materials like chitosan, dextran and elastin-like peptides (Bessa et al., 2010; Patois et al., 2009) are the most usually temperature-responsive polymers used: Among the $\mathrm{pH}$ sensitive carriers, the Poly (vinyl alcohol) and poly(acrylic acid) are amid the most common examples (Kurkuri and Aminabhavi, 2004; Zhang et al., 2012b). Moreover, also $\mathrm{pH}$-sensitive linkages such as hydrazone, hydrazide and acetal are extensively used for drug conjugation to a polymeric backbone (Fleige et al., 2012). As an example, for bone tissue engineering, in vivo analysis of a $\mathrm{pH} /$ thermo-sensitive sulphamethazine oligomers (SMO)-poly ( $\varepsilon$-caprolactone-co-lactide) (PCLA)-PEG-PCLA-SMO block copolymer loaded with human mesenchymal stem cells (hMSCs) and BMP-2 (Kim et al., 2009) showed hMSC differentiation for up to 7 weeks, mineralised tissue formation and high levels of alkaline phosphatase activity. For osteomyelitis treatment (Peng et al., 2010a; Peng et al., 2010b) developed a thermosensitive implant composed of PEG monomethyl ether (mPEG) and PLGA copolymer (mPEG-PLGA) for teicoplanin delivery. Histological staining and immunoblotting analyses in rabbits showed that the mPEG-PLGA hydrogel containing the antibiotic teicoplanin was effective in treating osteomyelitis (Peng et al., 2010b). In osteoarthritis, the delivery of the antiinflammatory celecoxib by a fully acetyl-capped PCLAPEG-PCLA triblock copolymer hydrogel showed to be a safe drug delivery platform for sustained intra-articular release (Petit et al., 2014).

In a different approach, the biochemically triggered drug release can be attained by incorporation of cleavable peptides for enzymatic degradation such as matrix metalloproteinase peptide crosslinkers (Chung et al., 2006; 
Fonseca et al., 2014; Kim et al., 2010; Lutolf et al., 2003). Enzyme-cleavable peptides can also be used to connect proteins and pro-drugs for delayed release and activation in response to cell infiltration (Arrighi et al., 2009; Purcell et al., 2014; Wilson and Guiseppi-Elie, 2013).

Additional drug release approaches in response to magnetic, ultrasound, irradiation and electric stimuli have also been explored (Torchilin, 2014). Magnetic nanoparticles are in fact a popular approach for local bone delivery allowing a controlled, spatio-temporal release of different drugs by the use of a magnetic field after implantation in vivo (Akbarzadeh et al., 2012; Li et al., 2016). Moreover, this also permits the creation of drug gradients and long term sustained release (Sensenig et al., 2012). In a study by Butoescu et al., dexamethasonecontaining superparamagnetic iron oxide nanoparticles (SPIONs) co-encapsulated into PLGA microparticles showed excellent biocompatibility with synoviocytes, and suggested that this type of carrier could be used as a suitable magnetically retainable intra-articular drug delivery system for treating joint diseases such as arthritis or osteoarthritis (Butoescu et al., 2009). For bone tissue engineering, in vitro analysis of clodronate loaded hydroxyapatitemagnetite-multi-walled carbon nanotubes nanocomposite showed good results as a multimodal platform combining the effect of bone biomineralisation induced by HApbased composites with the decrease of osteoclast formation induced by the drug (Pistone et al., 2014). In a different study, three-dimensional (3D) magnetic $\mathrm{Fe}_{3} \mathrm{O}_{4}$ nanoparticles containing mesoporous bioactive glass/ PCL $\left(\mathrm{Fe}_{3} \mathrm{O}_{4} / \mathrm{MBG} / \mathrm{PCL}\right)$ composite scaffolds loaded with doxorubicin as a model anticancer drug exhibited potential multifunctionality of enhanced osteogenic activity, local sustained drug release and magnetic hyperthermia in vitro (Jianhua Zhang, 2014).

\section{Combined delivery}

Bone healing involves the intervention of a complex and well spatio-temporal-orchestrated set of factors (Dimitriou et al., 2005; Tsiridis et al., 2007). In this regard, the incapacity to mimic the complex tissue architecture and to provide the necessary biochemical and cellular microenvironment is a major challenge in tissue regeneration.

Studies have shown that sequential and spatiotemporal drug release may lead to improved tissue regeneration by providing physiologically relevant release profiles and spatial gradients that mimic the natural healing response (Lee et al., 2011; Santo et al., 2013; Vo et al., 2012). The designing of multi-functional nanomaterials that enable the simultaneous, sequential and spatially-controlled delivery strategies of different therapeutics have been developed to recapitulate the early expression of factors for bone regeneration.

Several in vitro and in vivo studies have investigated the synergistic effects of dual growth factor delivery (BMP-2, BMP-7, VEGF, transforming growth factor (TGF)- $\beta$-3, Insulin-like growth factor 1 (IGF-1)) using different scaffold composites such as alginate, periodontal ligament fibroblasts, PLGA, gelatine and nanodiamonds, for numerous bone and cartilage regeneration applications (Basmanav et al., 2008; Chen et al., 2009; Facca et al., 2010; Kanczler et al., 2010; Moore et al., 2013; Park et al., 2009; Patel et al., 2008; Richardson et al., 2001; Simmons et al., 2004) showing improved results in comparison with the single delivery. In a recent study, the simultaneous delivery of BMP-2 and bFGF by nanodiamonds has showed good results for the promotion of bone cell differentiation and proliferation in vitro (Moore et al., 2013).

Combined delivery of growth factors and drugs has also been addressed as shown in a study of Choi et al., where a dual and time-controlled release of BMP2 and dexamethasone from PLGA-core/alginate-shell microcapsules fabricated with coaxial electro-dropping was investigated (Choi et al., 2010). In the past 5 years, MBGs have also been largely investigated for the combined delivery of therapeutic ions and drug/growth factors $(\mathrm{Wu}$ and Chang, 2014). Still, all in vivo reports of enhanced bone formation upon combined delivery of growth factors have been performed in ectopic, but not orthotopic models and further studies are necessary.

In a different approach, the time-dependence requirements of delivery have been investigated. Gelatine microparticles-loaded poly (propylene fumarate) scaffolds showed that bone formation in a rat calvarial critical size defect was BMP-2 dose-dependent and that VEGF combined delivery was beneficial on bone regeneration at 4 weeks, but not at 12 weeks (Patel et al., 2008; Young et al., 2009). Also, the sequential release of VEGF and BMP-2 from PLGA microsphere-loaded poly(propylene fumarate) scaffold-gelatine hydrogel composites in a rat femoral defect over 8 weeks showed suboptimal bone formation (Kempen et al., 2009).

In order to mimic the physiological concentration gradients that provide the topological signals for tissue formation, the impact of spatial delivery has also been addressed. Silk fibroin microspheres immobilised in a 3D porous silk scaffold where used for the simultaneous release of linear gradients of recombinant human BMP-2 and IGF-1 - showing enhanced osteogenic and chondrogenic differentiation of hMSCs over 5 weeks along the gradients (Wang et al., 2009).

Multilayered scaffolds constitute a unique platform that enables multiple delivery of therapeutics through incorporation of different phases into scaffolds for differential release kinetics and spatially controlled drug release. Bi-layered oligo(poly(ethylene glycol) fumarate) and gelatine microparticles hydrogels developed by (Guo et al., 2009; Guo et al., 2010) showed enhanced chondrogenic differentiation of encapsulated rabbit MSCs in vitro with delivery of TGF- $\beta 1$ or TGF- $\beta 3$ in the chondrogenic layer and co-culture with pre-differentiated osteogenic cells in the lower bone-forming layer (Guo et al., 2010; Guo et al., 2009). More recently, the potential of layer-by-layer technique has been successfully applied for the development of multilayered coating scaffolds for controlled drug delivery for orthopaedic implant applications (Kunjukunju et al., 2013; Min et al., 2014). 


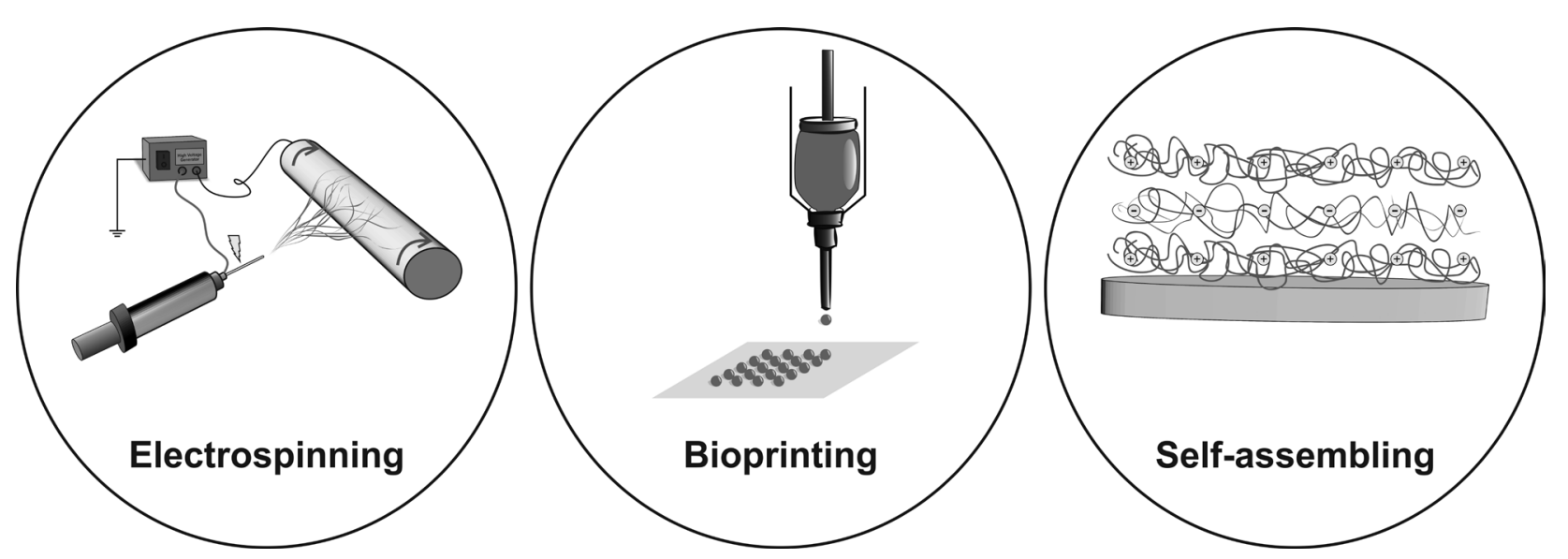

Fig. 2. Schematics of a) Electrospinning, b) Bioprinting, and c) Layered Scaffolds processing techniques.

\section{High-throughput processing techniques}

Manufacturing techniques like electrospinning, bioprinting, and layered scaffolds/membranes (Fig. 2), are among the latest techniques being pursued to produce tissue constructs and engineered scaffolds with pre-designed macro- microand nano- features, gradient physic-chemical properties and custom shapes for tissue engineering therapies.

Electrospinning is a technique that produces fibrous scaffolds and films through electrostatic repulsion of liquid polymer solutions using a high-voltage source creating nano/micron-sized fibres suitable for cell attachment and growth. Their orientation and geometries for therapeutics release can be controlled by collecting the extruded fibres on various static or rotating plates. Several studies reported sustained release of therapeutics to bone from electrospun scaffolds (Dong et al., 2014; Lee et al., 2014; Mi et al., 2014; Ramier et al., 2014; Ren et al., 2014; Sahoo et al., 2010; Srouji et al., 2011; Tetteh et al., 2014). As an example, in a study by Sahoo et al., PLGA nanofibers incorporated with bFGF, fabricated using the facile technique of blending and electrospinning (Group I) and by the more complex technique of coaxial electrospinning (Group II) presented prolonged growth factor release that positively influenced stem cell behaviour and fate (Sahoo et al., 2010).

Moreover, exciting new technology such as biopatterning offers a more precise and efficient control of drug delivery than conventional techniques. Biopatterning is a promising approach in bone tissue engineering, used to immobilise growth factors and cells onto 3D scaffolds with persistent patterns that subsequently control cell migration, proliferation and differentiation. In this technique a precise positioning of biological materials, biochemicals and living cells, with spatial control of the placement of functional components, is used to fabricate 3D structures (Guillemot et al., 2010). Cooper et al. used acellular-derma-matrix constructs patterned with BMP-2 and signalling noggin protein implanted into a mouse calvarial defect model showing that three-dimensional biopatterning of a growth factor and growth factor modifier within a construct can direct cell differentiation in vitro and tissue formation in vivo according to printed patterns (Cooper et al., 2010). In a similar study, Herberg et al. showed that sustained release delivery of a low-dose growth factor therapy (BMP-2, stromal cell-derived factor- $1 \beta$ and TGF- $\beta 1$ ), and co-therapies using inkjet-based biopatterning of acellularderma-matrix can aid healing in mouse calvarial critical size defect (Herberg et al., 2014). Gao et al. evaluate bioactive ceramic nanoparticles (glass (BG) and hydroxyapatite) in stimulating osteogenesis of printed bone marrow-derived hMSCs in poly(ethylene glycol) dimethacrylate scaffold. Results highlighted the technology capacity cell delivery into hard tissue engineering with biomimetic structures (Gao et al., 2014). This strategy enables the design of spatially customised anatomical architecture in a patientand defect-specific manner.

Layer-by-layer assembly of nanoparticles and coatings allows for the modification of the material's surface properties, enabling a controlled release of desirable substances (Min et al., 2014). By using this technique, stronger bonding of implants to bones can be achieved as well as the controlled release of antibiotics or antimicrobial agents to prevent infection (Gaudiere et al., 2014; Hu et al., 2010; Li et al., 2012; Shah et al., 2013; Yang et al., 2009).

A list of currently ongoing approaches for the biomaterial-based delivery of therapeutics for different bone diseases is listed in Table 4 .

\section{In silico mathematical models for the skeletal system}

Mathematical modelling has been shown to be an important tool in the optimisation of drug delivery systems (Siepmann and Siepmann, 2008). Advanced modelling and in silico experiments can be useful in different components of the optimisation process, such as calculation of optimal drug release profiles (Raiche and Puleo, 2001) specification of structure and dimensions of delivery systems (Velghe et al., 2014), or to speed up product development (Siepmann and Siepmann, 2012), just to name a few.

Mathematical and computational models provide detailed quantitative descriptions of a system by capturing, in one or more mathematical expressions, its main dynamics and properties. Models are, of course, an abstraction of the real systems, with underlying simplifications and assumptions, but have the potential to isolate and quantitatively describe the mechanisms of 
Table 4a. Biomaterial-based delivery of therapeutics for bone diseases.

\begin{tabular}{|c|c|c|c|c|}
\hline Therapeutic agent & Biomaterial & Delivery & Model of study & References \\
\hline \multicolumn{5}{|l|}{ Osteoporosis } \\
\hline Sim & CaP nanocapsules & injection & in vivo, ovariectomised mouse & Ito et al., 2013 \\
\hline Alen & CaP cement & implant & in vitro, rat mesenchymal stem cells & Jindong et al., 2010 \\
\hline \multirow[t]{2}{*}{ Zol } & $\mathrm{CaP}$ & injection & in vivo, ovariectomised rat and sheep & Verron et al., 2010 \\
\hline & $\begin{array}{l}\text { HAp plasma-coated } \mathrm{Ti} \\
\text { alloy cylinders }\end{array}$ & implant & in vivo, ovariectomised sheep & Stadelmann et al., 2008) \\
\hline \multirow[t]{2}{*}{ PTH 1-34 } & CH NPs & multiple routes & in vitro, Saos- 2 cells & Narayanan et al., 2012 \\
\hline & $\begin{array}{l}\begin{array}{l}\text { microneedle patch } \\
\text { system }\end{array} \\
\end{array}$ & transdermal & phase 2 clinical trials & Daddona et al., 2011 \\
\hline $\mathrm{Zol}+\mathrm{bFGF}$ & HAp-coated Ti implant: & implant & in vivo, ovariectomised rats & Gao et al., 2009 \\
\hline rhBMP-7 & $\begin{array}{l}\text { PLGA NS onto nano- } \\
\text { fibrous PLLA scaffolds }\end{array}$ & implant & in vivo, rats & Wei et al., 2007 \\
\hline Oestrogen & $\mathrm{CaPC}$ & implant & in vivo, rats & Otsuka et al., 2000 \\
\hline Ris & polymeric NPs & intranasal & $\begin{array}{l}\text { ex vivo, porcine fresh nasal mucosa; and In } \\
\text { vivo, aged rats }\end{array}$ & Fazil et al., 2015 \\
\hline siRNA (Plekho1) & $\begin{array}{l}\text { (DOTAP)-(AspSerSer) } \\
\text { (6) liposomes }\end{array}$ & injection & in vivo, osteoporotic rats & Zhang et al., 2012a \\
\hline Plasmid DNA & $\mathrm{CH}$ & --- & in vitro, MSCs, MG63 and HEK293 & Corsi et al., 2003 \\
\hline \multicolumn{5}{|l|}{ Fractures } \\
\hline FTY720 & $\begin{array}{l}\text { PLGA-coated deminer- } \\
\text { alised allograph }\end{array}$ & implant & in vivo, critical-size rat tibial defect & Petrie Aronin et al., 2010 \\
\hline Pur & HAp & implant & in vivo; foetal chick femur & Gellynck et al., 2013 \\
\hline \multirow[t]{2}{*}{$\operatorname{Sim}$} & $\mathrm{CaS}$ & implant & in vivo, rat tíbia osteotomy & Qi et al., 2013 \\
\hline & $\begin{array}{l}\text { PLGA/HAp } \\
\text { microspheres }\end{array}$ & $\begin{array}{l}\text { local administra- } \\
\text { tion }\end{array}$ & $\begin{array}{l}\text { in vivo, mouse model of gap fracture bridging } \\
\text { with a graft of necrotic bone }\end{array}$ & Tai et al., 2013 \\
\hline Lov & Polyurethane scaffolds & implant & $\begin{array}{l}\text { in vivo, critical-sized segmental defect in rat } \\
\text { femora }\end{array}$ & Yoshii et al., 2014 \\
\hline Ros & Collagen sponge & implant & in vivo, critical-size rabbit cortical bone defect & Monjo et al., 2010 \\
\hline Helioxanthin & $\begin{array}{l}\text { CaP granules } \\
\text { (Tetrabone } \AA)\end{array}$ & implant & in vivo, Rat Femur bone defect & Maeda et al., 2013 \\
\hline BMP-2 & PLA-NPs & not disclosed & in vitro, microculture tetrazolium test & Chen et al., 2011a \\
\hline FGF-2 & B-TCP / Collagen & injectable & in vivo, rabbit tibia segmental defect & Komaki et al., 2006 \\
\hline TGF-ss 1 & $\begin{array}{l}\mathrm{CaP} / \text { Gelatine } \\
\text { microparticles }\end{array}$ & injectable & in vivo, rabbit femoral bone defect & Link et al., 2008 \\
\hline BMP-2, ASCs & $\begin{array}{l}\text { 3D apatite-coated } \mathrm{CH} / \\
\mathrm{CS} \text { scaffold }\end{array}$ & implant & $\begin{array}{l}\text { in vivo, rat critical-sized mandibular defect } \\
\text { model. }\end{array}$ & Fan et al., 2014 \\
\hline BMP-2 & $\begin{array}{l}\text { Heparin/apatite-coated } \\
\text { implant }\end{array}$ & local implant & in vivo, rat tibial defect & Ishibe et al., 2009 \\
\hline siRNA (Noggin) & PLA-DX-PEG hydrogel & implant & in vivo, mouse dorsal muscle pouche & Manaka et al., 2011 \\
\hline $\begin{array}{l}\text { shRNAs (osteopon- } \\
\text { tin or osteocalcin) }\end{array}$ & $\begin{array}{l}\text { Multi-shell calcium } \\
\text { phosphate NPs } \\
\text { incorporated into a PLL } \\
\text { multilayered film }\end{array}$ & --- & in vitro, human osteoblasts & Zhang et al., 2010 \\
\hline NO & $\mathrm{CH}$ & local implant & in vivo, rat femur fracture model. & Diwan et al., 2000 \\
\hline $\mathrm{NO}$ & $\begin{array}{l}\text { Demineralised bone } \\
\text { matrix }\end{array}$ & local implant & in vivo, rat femur fracture model & Baldik et al., 2002 \\
\hline
\end{tabular}

Abbreviations are listed in Table 1.

interest and its causal dependencies. Two key concepts underlie the use of mathematical models in the optimisation of drug delivery systems, as in other research fields: 1) hypothesis testing - assess if a conceptual model is in fact a proper description of the mechanism(s) of interest in the real system; and 2) prediction - given partial information about the state and parameters of the system, be able to infer unknown variables (usually prediction is used in the context of producing estimates for variables of interest at future time instants). Both situations have been used in the quest to better understand and optimise the drug delivery systems (Peppas, 2013; Siepmann and Peppas, 2001a; Siepmann and Siepmann, 2008).

In order to capture and predict the spatiotemporal properties of drug delivery, existing mathematical models focus on the following mechanisms associated with the delivery system: diffusion, swelling, erosion and drug binding affinity (Arifin et al., 2006; Lauzon et al., 2012; Siepmann and Siepmann, 2008). While for presentation purposes the following section addresses each one of these mechanisms separately, in practise most models blend together these theories in order to produce more realistic descriptions of the drug delivery systems. This means that different types of scaffolds developed for drug delivery typically require more than one of the above mentioned core mechanisms to be properly modelled. Mathematical models, independently of the mechanism they try to describe, can either be empirical or mechanistic depending on the level of simplification used: mechanistic models include an explicit representation of mass transport mechanisms and biochemical reactions (Korsmeyer et al., 1986a); empirical models try to directly capture the 
Table 4b. Biomaterial-based delivery of therapeutics for bone diseases.

\begin{tabular}{|c|c|c|c|c|}
\hline Therapeutic agent & Biomaterial & Delivery & Model of study & References \\
\hline \multicolumn{5}{|c|}{ Bone Cancer and bone metastasis } \\
\hline Ris & PLL-CD & $\begin{array}{l}\begin{array}{l}\text { subcutaneous } \\
\text { injection }\end{array} \\
\end{array}$ & $\begin{array}{l}\text { in vivo, } \mathrm{BALB} / \mathrm{c} \text { nu/nu mice injected with } \\
\text { CHO- } \beta_{3} \text { tumour cells }\end{array}$ & Daubine et al., 2009 \\
\hline Zol -Docetaxel & PLGA-PEG & $\begin{array}{l}\text { intravenous } \\
\text { injection }\end{array}$ & $\begin{array}{l}\text { in vitro (MCF7 and } \mathrm{BO} 2 \text { cell lines) and In vivo } \\
\text { (Swiss mice with induced femoral tumour) }\end{array}$ & $\begin{array}{l}\text { Ramanlal Chaudhari et } \\
\text { al., } 2012\end{array}$ \\
\hline Alen & PLGA & $\begin{array}{l}\text { systemic } \\
\text { administration }\end{array}$ & $\begin{array}{l}\text { in vitro(human venous blood, HUVECs, and } \\
\text { human primary osteoblasts) }\end{array}$ & Pignatello et al., 2009 \\
\hline \multirow[t]{4}{*}{ Dox } & PLGA & $\begin{array}{l}\text { systemic } \\
\text { administration }\end{array}$ & $\begin{array}{l}\text { in vivo, orthotopic mouse model of breast cancer } \\
\text { bone metastases }\end{array}$ & Salerno et al., 2010 \\
\hline & alpha-AL-HPLN & $\begin{array}{l}\text { systemic } \\
\text { administration }\end{array}$ & in vitro, osteosarcoma cell lines & Federman et al., 2012 \\
\hline & $\begin{array}{l}\begin{array}{l}\text { Lipid-modified dextran } \\
\text { based polymeric NPs }\end{array} \\
\end{array}$ & \begin{tabular}{|c|}
---- \\
-1
\end{tabular} & in vitro, osteosarcoma cell lines & Susa et al., 2009 \\
\hline & Dextran-PEI NPs & ----- & in vitro, Osteosarcoma cell lines & Sun et al., 2011 \\
\hline $\begin{array}{l}\text { PTX-PEG-Alen } \\
\text { conjugate }\end{array}$ & PTX and Alen & systemic injection & in vitro, $\mathrm{PC} 3$ cells. & Clementi et al., 2011 \\
\hline 20(S)-Camptothecin & $\begin{array}{l}\text { Cyclodextrin-based } \\
\text { polymer }\end{array}$ & $\begin{array}{l}\text { intravenous } \\
\text { injection }\end{array}$ & in vivo, mouse xenografts cancer models & Schluep et al., 2006 \\
\hline MTX & LDH & --- & in vitro, Saos- 2 cell line & Oh et al., 2011 \\
\hline ATO & $\begin{array}{l}\text { Magnetic nanoparticles } \\
\text { encapsulated by PLA. }\end{array}$ & $\begin{array}{l}\text { intravenous } \\
\text { injection }\end{array}$ & in vivo, mouse osteosarcoma tumour models & Li et al., 2007b \\
\hline Cisplatin & CaP Nps & --- & in vitro, $\mathrm{K} 8$ clonal murine osteosarcoma cell line & Barroug et al., 2004 \\
\hline siRNA (FLi1 gene) & $\begin{array}{l}\text { PEI and PAH coated } \\
\text { ND. }\end{array}$ & --- & in vitro, Ewing sarcoma cells & Alhaddad et al., 2011 \\
\hline siRNA (PLK1 gene) & Diblock copolymer & --- & in vitro, osteosarcoma cell line & Truong et al., 2013 \\
\hline \multicolumn{5}{|l|}{ Arthroplasties } \\
\hline rhBMP-2 & Carbon nanotubes & implant & in vivo, mouse & Usui et al., 2008 \\
\hline BMP-2 & $\begin{array}{l}\text { CH-tripolyphosphate } \\
\text { (CH-TPP) } \\
\text { nanoparticles }\end{array}$ & implant & in vivo, mouse & Poth et al., 2015 \\
\hline \multicolumn{5}{|l|}{ Osteoarthritis } \\
\hline Osteoarthritis drug & $\begin{array}{l}\text { nanoparticles-in- } \\
\text { microspheres }\end{array}$ & $\begin{array}{l}\text { intra-articular } \\
\text { injection }\end{array}$ & in vivo, rat model & Chen et al., 2014 \\
\hline Dextran & Polymeric hydrogel & $\begin{array}{l}\text { intra-articular } \\
\text { injection }\end{array}$ & in vivo, rat model & Morgen et al., 2013 \\
\hline Plasmid DNA & CH NPs & $\begin{array}{l}\text { intra-articular } \\
\text { injection }\end{array}$ & in vivo, osteoarthritis rabbits & Zhang et al., 2006 \\
\hline Plasmid DNA & HA-CH & --- & in vitro, chondrocyte cell culture & Lu et al., 2011 \\
\hline $\begin{array}{l}\text { siRNA }(\text { ERK } 1 / 2 \\
\text { gene) }\end{array}$ & Diblock copolymer & --- & in vitro, osteosarcoma cell line & Truong et al., 2013 \\
\hline \multicolumn{5}{|c|}{ Infectious and inflammatory bone diseases } \\
\hline Dox & $\begin{array}{l}\text { 3D PLGA NS } \\
\text { incorporated into } \\
\text { prefabricated } \\
\text { nanofibrous PLLA } \\
\text { scaffolds }\end{array}$ & --- & in vitro, antibacterial tests & Feng et al., 2010 \\
\hline Teicoplanin & $\begin{array}{l}\text { mPEG-PLGA } \\
\text { termosensitive } \\
\text { hydrogel } \\
\end{array}$ & local injection & in vivo, rabbit osteomyelitis model & Peng et al., 2010a \\
\hline Tigecycline & CaP-PLGA NPs & implant & in vivo, rat & Ignjatovic et al., 2010 \\
\hline $\begin{array}{l}\text { Small molecule } \\
\text { drug model, } \\
\text { fluorescein }\end{array}$ & $\mathrm{HAp} / \mathrm{CH}$ particles & ---- & in vitro, $\mathrm{MC} 3 \mathrm{~T} 3-\mathrm{E} 1$ cells & $\begin{array}{l}\text { Uskokovic and Desai, } \\
2014\end{array}$ \\
\hline Antibiotic & CPs & ---- & in vitro, MC3T3-E1 cells & $\begin{array}{l}\text { Uskokovic and Desai, } \\
2013\end{array}$ \\
\hline CFS & $\begin{array}{l}\text { Micro- to macro- } \\
\text { porous hydroxyapatite } \\
\text { scaffolds }\end{array}$ & implant & $\begin{array}{l}\text { in vivo, rabbit tibia osteomyelitis animal model } \\
\text { and In vivo human bone. }\end{array}$ & $\begin{array}{l}\text { Bhattacharya et al., } \\
2013\end{array}$ \\
\hline VCM & bioactive glass ceramics & ---- & in vitro, rat osteoblastic-like cells & $\begin{array}{l}\text { Thanyaphoo and } \\
\text { Kaewsrichan, } 2012\end{array}$ \\
\hline $\mathrm{NO}$ & $\begin{array}{l}\text { xerogel-coated implant } \\
\text { pins }\end{array}$ & implant & in vivo, rat & Holt et al., 2011 \\
\hline
\end{tabular}

Abbreviations are listed in Table 1. 
drug release profiles without explicitly stating the internal generating mechanisms (Higuchi, 1961; Peppas, 1985).

While mathematical and computational models of drug delivery is a field in rapid development, very few studies exist in the context of the skeletal system (Lauzon et al., 2012; Lauzon et al., 2014; Makarov et al., 2014; Raiche and Puleo, 2001).

\section{Models for diffusion controlled systems}

Mechanistic models for diffusion controlled systems are grounded in the principle of mass conservation. This principle states that in a closed system, total mass is conserved: it can neither be created nor destroyed, but it can be rearranged in space (through the action of fluxes). Given its dependence in both space and time, mechanistic models for diffusion controlled systems need to be described by partial differential equations, relating the drug concentration $(C)$, with transport mechanisms (flux, $F)$ and the existing drug sources and sinks $(f)$ :

$$
\frac{\partial C}{\partial t}+\vec{\nabla} \cdot \vec{F}=f
$$

The symbol $\vec{\nabla}$ represents the mathematical operator divergence. The physical significance of the divergence of the flux $F$ can be seen as the rate at which drug density exits a given region of space (Fig 3 ). Each of the variables $C, F$ and $f$ may be functions of both time and space.

In the absence of transport mechanisms other than diffusion, the flux is given by Fick's first law:

$$
F^{\rightarrow}=-D \nabla C \quad 2
$$

where $D$ is the diffusion coefficient (which may also be a function of time and space). Initial conditions, geometry and boundary conditions all play a crucial role in the solutions of the mass conservation equation. One of the most frequently used approaches is to discard interactions of the active molecules with the environment and consider only the pseudo steady-state (Higuchi, 1961; Siepmann and Peppas, 2011). Other models have, however, considered less simplified conditions (Makarov et al., 2014; Siepmann and Siepmann, 2012; Tzafriri et al., 2005) including different geometries (Grassi and Grassi, 2005; Helbling et al., 2011; Raiche and Puleo, 2001), moving boundaries (Manitz et al., 1998), hydrogel network design (Lin and Metters, 2006), drug dissolution (Siepmann and Siepmann, 2013), and vesicle design (Mosley et al., 2013).

\section{Models for swelling controlled systems}

Some polymer matrix delivery systems are subject to polymer swelling with important consequences in the properties and dynamics of drug release. This swelling affects transit times and diffusion properties by increasing the volume and changing the properties of the medium where the flux is taking place. Altering the diffusion pathways, and subsequently the concentration gradients, can produce significant changes in the drug release properties (Siepmann and Siepmann, 2008). Models

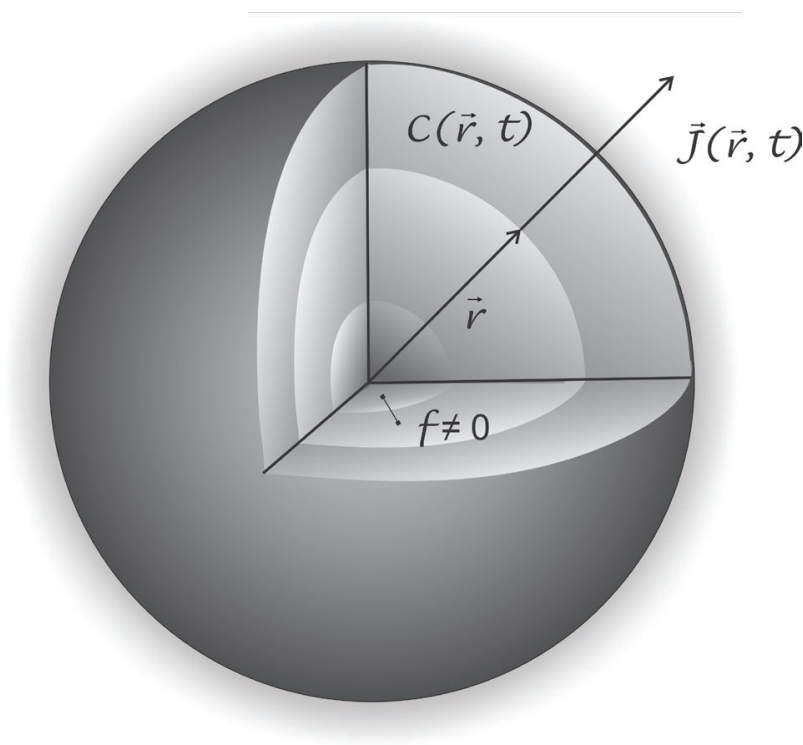

Fig. 3. Principle of mass conservation in a system with spherical symmetry. The nanoparticles/drug concentration, as a function of time and distance to the delivery system core, is described by the present fluxes $J$ (e.g., diffusive) and the delivery and degradation dynamics, captured in the component $f$.

dealing with swelling are therefore more complex than simple diffusion models, as they have to account for changing geometries and/or boundary conditions as well as inhomogeneous diffusion coefficients (Korsmeyer et al., 1986a; Korsmeyer et al., 1986b; Siepmann and Peppas, 2001b).

\section{Models for erosion controlled systems}

Polymer erosion and degradation are other properties that can be carefully engineered to enhance tissue treatment. In the case of bone repair, generally the scaffolds must be resorbed to provide efficient healing (Lauzon et al., 2012). The process of erosion/degradation can be modelled as a combination of stochastic hydrolysis and mass transport (Chen et al., 2011b), autocatalytic hydrolysis (Ford Versypt et al., 2013), diffusion and chemical reactions (Siepmann and Gopferich, 2001). An extensive review of different mathematical models addressing polymer erosion of the context of drug delivery is presented in (Sackett and Narasimhan, 2011).

\section{Models for affinity controlled systems}

In some delivery systems the interactions between drug and scaffold need to be accounted for in order to produce a plausible and realistic model of the drug release. In these models the mass conservation equation together with Fick's first law are used in combination with biochemical (kinetics) equations describing the affinity interactions (Fu et al., 2011; Lauzon et al., 2012; Lauzon et al., 2014). 


\section{Conclusions and future perspectives}

The relevance of nanobiotechnology in the improvement of drug delivery systems is now unquestionable and assumes a central role in the progression of human therapeutics.

Recent research has clearly demonstrated the potential of nanotechnology in the development of drug delivery systems to a vast range of bone disorders. Present pharmaceutical efforts are shifting from the search for new drugs into the investigation of novel approaches that enable a specific and targeted delivery of therapeutics to bone that may improve drug efficiency and patient compliance, while minimising adverse side-effects. Targeted delivery systems based on bone seeking agents resulted in enhanced distribution of therapeutic agents to bone tissue. Local administration based on nanoparticles and hydrogels that slowly released incorporated drugs presented a sustained therapeutic effect in disease site and most recently, smart drug delivery systems that respond to various stimuli have been investigated to attain the controlled and site-specific delivery of drugs. Complementary, diverse high throughput technologies and in silico approaches are currently facing a steep development and improvement. By enabling the precise processing of materials and the establishment of very fine mathematical formulation, comprising highly tuneable/case-specific parameters, such technologies represent a very exciting step forward for the achievement of the desired personalised drug delivery approach.

Although offering great potential, significant challenges and limitations in this field must be addressed in order to make drug delivery systems to bone an effective clinical reality. One of the major handicaps is the lack of knowledge of the pathological and biochemical pathways involved in specific disease states. A deeper understanding of the disease-specific underlying mechanisms and time frames would allow the design of more accurate tailored systems with enhanced effectiveness and the development of precise synergistic drug delivery systems to bone.

Nanobiotechnology-based drug delivery strategies to bone have a very wide range of applications and represent an exciting and very promising field of research with the potential to significantly improve the quality of life for millions of people.

\section{Acknowledgments}

This work was financed by FEDER - Fundo Europeu de Desenvolvimento Regional funds through the COMPETE 2020 - Operacional Programme for Competitiveness and Internationalisation (POCI), Portugal 2020, and by Portuguese funds through FCT - Fundação para a Ciência e a Tecnologia/ Ministério da Ciência, Tecnologia e Inovação in the framework of the project "Institute for Research and Innovation in Health Sciences" (POCI-01-0145FEDER-007274). Inês Soares Alencastre, Cecília Juliana Alves and Estrela Neto were granted by FCT (Alencastre IS- SFRH/ BPD/75285/2010; Alves CJ- SFRH / BPD / 63618 / 2009; Neto E - SFRH/BD/81152/2011).

\section{References}

Agyin JK, Santhamma B, Roy SS (2013) Design, synthesis, and biological evaluation of bone-targeted proteasome inhibitors for multiple myeloma. Bioorg Med Chem Lett 23: 6455-6458.

Akbarzadeh A, Samiei M, Davaran S (2012) Magnetic nanoparticles: preparation, physical properties, and applications in biomedicine. Nanoscale Res Lett 7: 144.

Alcaide M, Portoles P, Lopez-Noriega A, Arcos D, Vallet-Regi M, Portoles MT (2010) Interaction of an ordered mesoporous bioactive glass with osteoblasts, fibroblasts and lymphocytes, demonstrating its biocompatibility as a potential bone graft material. Acta Biomater 6: 892-899.

Alexis F, Pridgen E, Molnar LK, Farokhzad OC (2008) Factors affecting the clearance and biodistribution of polymeric nanoparticles. Mol Pharm 5: 505-515.

Alhaddad A, Adam MP, Botsoa J, Dantelle G, Perruchas S, Gacoin T, Mansuy C, Lavielle S, Malvy C, Treussart F, Bertrand JR (2011) Nanodiamond as a vector for siRNA delivery to Ewing sarcoma cells. Small 7: 3087-3095.

Anderson PM, Subbiah V, Rohren E (2014) Boneseeking radiopharmaceuticals as targeted agents of osteosarcoma: samarium-153-EDTMP and radium-223. Adv Exp Med Biol 804: 291-304.

Arifin DY, Lee LY, Wang CH (2006) Mathematical modeling and simulation of drug release from microspheres: Implications to drug delivery systems. Adv Drug Deliv Rev 58: 1274-1325.

Arrighi I, Mark S, Alvisi M, von Rechenberg B, Hubbell JA, Schense JC (2009) Bone healing induced by local delivery of an engineered parathyroid hormone prodrug. Biomaterials 30: 1763-1771.

Awasthi VD, Garcia D, Goins BA, Phillips WT (2003) Circulation and biodistribution profiles of long-circulating PEG-liposomes of various sizes in rabbits. Int J Pharm 253: 121-132.

Baldik Y, Talu U, Altinel L, Bilge H, Demiryont M, Aykac-Toker G (2002) Bone healing regulated by nitric oxide: an experimental study in rats. Clin Orthop Relat Res 404: 343-352.

Barroug A, Kuhn LT, Gerstenfeld LC, Glimcher MJ (2004) Interactions of cisplatin with calcium phosphate nanoparticles: in vitro controlled adsorption and release. J Orthop Res 22: 703-708.

Basak S, Nanda J, Banerjee A (2014) Multi-stimuli responsive self-healing metallo-hydrogels: tuning of the gel recovery property. Chem Commun (Camb) 50: 23562359.

Basmanav FB, Kose GT, Hasirci V (2008) Sequential growth factor delivery from complexed microspheres for bone tissue engineering. Biomaterials 29: 4195-4204.

Bauss F, Esswein A, Reiff K, Sponer G, MullerBeckmann B (1996) Effect of 17beta-estradiolbisphosphonate conjugates, potential bone-seeking estrogen pro-drugs, on 17beta-estradiol serum kinetics and bone mass in rats. Calcif Tissue Int 59: 168-173.

Benoit DS, Boutin ME (2012) Controlling mesenchymal stem cell gene expression using polymer-mediated delivery of siRNA. Biomacromolecules 13: 3841-3849. 
Bessa PC, Machado R, Nurnberger S, Dopler D, Banerjee A, Cunha AM, Rodriguez-Cabello JC, Redl H, van Griensven M, Reis RL, Casal M (2010) Thermoresponsive self-assembled elastin-based nanoparticles for delivery of BMPs. J Control Release 142: 312-318.

Bhandari KH, Newa M, Uludag H, Doschak MR (2010) Synthesis, characterization and in vitro evaluation of a bone targeting delivery system for salmon calcitonin. Int J Pharm 394: 26-34.

Bhattacharya R, Kundu B, Nandi SK, Basu D (2013) Systematic approach to treat chronic osteomyelitis through localized drug delivery system: bench to bed side. Mater Sci Eng C Mater Biol Appl 33: 3986-3993.

Bose S, Tarafder S (2012) Calcium phosphate ceramic systems in growth factor and drug delivery for bone tissue engineering: a review. Acta Biomater 8: 1401-1421.

Butoescu N, Seemayer CA, Foti M, Jordan O, Doelker E (2009) Dexamethasone-containing PLGA superparamagnetic microparticles as carriers for the local treatment of arthritis. Biomaterials 30: 1772-1780.

Caldorera-Moore M, Peppas NA (2009) Microand nanotechnologies for intelligent and responsive biomaterial-based medical systems. Adv Drug Deliv Rev 61: 1391-1401.

Chaudhari KR, Kumar A, Khandelwal VKM, Mishra AK, Monkkonen J, Murthy RSR (2012) Targeting efficiency and biodistribution of zoledronate conjugated docetaxel loaded pegylated PBCA Nanoparticles for bone metastasis. Advanced Functional Materials 22: 4101-4114.

Chen FM, Chen R, Wang XJ, Sun HH, Wu ZF (2009) In vitro cellular responses to scaffolds containing two microencapulated growth factors. Biomaterials 30: 52155224.

Chen L, Liu L, Li C, Tan Y, Zhang G (2011a) A new growth factor controlled drug release system to promote healing of bone fractures: nanospheres of recombinant human bone morphogenetic-2 and polylactic acid. J Nanosci Nanotechnol 11: 3107-3114.

Chen Y, Zhou S, Li Q (2011b) Mathematical modeling of degradation for bulk-erosive polymers: applications in tissue engineering scaffolds and drug delivery systems. Acta Biomater 7: 1140-1149.

Chen Z, Liu D, Wang J, Wu L, Li W, Chen J, Cai BC, Cheng H (2014) Development of nanoparticles-inmicroparticles system for improved local retention after intra-articular injection. Drug Deliv 21: 342-350.

Chi B, Park SJ, Park MH, Lee SY, Jeong B (2010) Oligopeptide delivery carrier for osteoclast precursors. Bioconjug Chem 21: 1473-1478.

Choi DH, Park CH, Kim IH, Chun HJ, Park K, Han DK (2010) Fabrication of core-shell microcapsules using PLGA and alginate for dual growth factor delivery system. J Control Release 147: 193-201.

Chun C, Lim HJ, Hong KY, Park KH, Song SC (2009) The use of injectable, thermosensitive poly(organophosphazene)-RGD conjugates for the enhancement of mesenchymal stem cell osteogenic differentiation. Biomaterials 30: 6295-6308.

Chung EH, Gilbert M, Virdi AS, Sena K, Sumner DR, Healy KE (2006) Biomimetic artificial ECMs stimulate bone regeneration. J Biomed Mater Res A 79: 815-826.
Cirillo G, Hampel S, Spizzirri UG, Parisi OI, Picci N, Iemma F (2014) Carbon nanotubes hybrid hydrogels in drug delivery: a perspective review. Biomed Res Int 2014: 825017.

Clementi C, Miller K, Mero A, Satchi-Fainaro R, Pasut G (2011) Dendritic poly(ethylene glycol) bearing paclitaxel and alendronate for targeting bone neoplasms. Mol Pharm 8: 1063-1072.

Cooper GM, Miller ED, Decesare GE, Usas A, Lensie EL, Bykowski MR, Huard J, Weiss LE, Losee JE, Campbell PG (2010) Inkjet-based biopatterning of bone morphogenetic protein-2 to spatially control calvarial bone formation. Tissue Eng Part A 16: 1749-1759.

Corsi K, Chellat F, Yahia L, Fernandes JC (2003) Mesenchymal stem cells, MG63 and HEK293 transfection using chitosan-DNA nanoparticles. Biomaterials 24: 1255 1264.

Daddona PE, Matriano JA, Mandema J, Maa YF (2011) Parathyroid hormone (1-34)-coated microneedle patch system: clinical pharmacokinetics and pharmacodynamics for treatment of osteoporosis. Pharm Res 28: 159-165.

Daubine F, Cortial D, Ladam G, Atmani H, Haikel Y, Voegel JC, Clézardin P, Benkirane-Jessel N (2009) Nanostructured polyelectrolyte multilayer drug delivery systems for bone metastasis prevention. Biomaterials 30: 6367-6373.

de Miguel L, Noiray M, Surpateanu G, Iorga BI, Ponchel G (2014) Poly(gamma-benzyl-L-glutamate)-PEGalendronate multivalent nanoparticles for bone targeting. Int J Pharm 460: 73-82.

Decuzzi P, Godin B, Tanaka T, Lee SY, Chiappini C, Liu X, Ferrari M (2010) Size and shape effects in the biodistribution of intravascularly injected particles. J Control Release 141: 320-327.

Delaisse JM (2014) The reversal phase of the boneremodeling cycle: cellular prerequisites for coupling resorption and formation. Bonekey Rep 3: 561.

Demers P, Fraser D, Goldbloom RB, Haworth JC, LaRochelle J, MacLean R, Murray TK (1968) Effects of tetracyclines on skeletal growth and dentition. A report by the Nutrition Committee of the Canadian Paediatric Society. Can Med Assoc J 99: 849-854.

des Rieux A, Fievez V, Garinot M, Schneider YJ, Preat V (2006) Nanoparticles as potential oral delivery systems of proteins and vaccines: a mechanistic approach. J Control Release 116: 1-27.

Dimitriou R, Tsiridis E, Giannoudis PV (2005) Current concepts of molecular aspects of bone healing. Injury 36: 1392-1404.

Diwan AD, Wang MX, Jang D, Zhu W, Murrell GA (2000) Nitric oxide modulates fracture healing. J Bone Miner Res 15: 342-351.

Dodson TB (2009) Intravenous bisphosphonate therapy and bisphosphonate-related osteonecrosis of the jaws. J Oral Maxillofac Surg 67: 44-52.

Dong S, Sun J, Li Y, Li J, Cui W, Li B (2014) Electrospun nanofibrous scaffolds of poly (L-lactic acid)dicalcium silicate composite via ultrasonic-aging technique for bone regeneration. Mater Sci Eng C Mater Biol Appl 35: 426-433. 
Doschak MR, Kucharski CM, Wright JE, Zernicke RF, Uludag H (2009) Improved bone delivery of osteoprotegerin by bisphosphonate conjugation in a rat model of osteoarthritis. Mol Pharm 6: 634-640.

El-Mabhouh AA, Angelov CA, Cavell R, Mercer JR (2006) A 99mTc-labeled gemcitabine bisphosphonate drug conjugate as a probe to assess the potential for targeted chemotherapy of metastatic bone cancer. Nucl Med Biol 33: 715-722.

Facca S, Cortez C, Mendoza-Palomares C, Messadeq N, Dierich A, Johnston AP, Mainard D, Voegel JC, Caruso F, Benkirane-Jessel N (2010) Active multilayered capsules for in vivo bone formation. Proc Natl Acad Sci U S A 107: 3406-3411.

Fan J, Park H, Lee MK, Bezouglaia O, Fartash A, Kim J, Aghaloo T, Lee M (2014) Adipose-derived stem cells and BMP-2 delivery in chitosan-based $3 \mathrm{D}$ constructs to enhance bone regeneration in a rat mandibular defect model. Tissue Eng Part A 20: 2169-2179.

Fang J, Nakamura H, Maeda H (2011) The EPR effect: Unique features of tumor blood vessels for drug delivery, factors involved, and limitations and augmentation of the effect. Adv Drug Deliv Rev 63: 136-151.

Fazil M, Hassan MQ, Baboota S, Ali J (2015) Biodegradable intranasal nanoparticulate drug delivery system of risedronate sodium for osteoporosis. Drug Deliv 25: 1-11.

Federman N, Chan J, Nagy JO, Landaw EM, McCabe K, Wu AM, Triche T, Kang H, Liu B, Marks JD, Denny CT (2012) Enhanced growth inhibition of osteosarcoma by cytotoxic polymerized liposomal nanoparticles targeting the alcam cell surface receptor. Sarcoma 2012: 126906.

Feng K, Sun H, Bradley MA, Dupler EJ, Giannobile WV, Ma PX (2010) Novel antibacterial nanofibrous PLLA scaffolds. J Control Release 146: 363-369.

Fleige E, Quadir MA, Haag R (2012) Stimuliresponsive polymeric nanocarriers for the controlled transport of active compounds: concepts and applications. Adv Drug Deliv Rev 64: 866-884.

Fonseca KB, Gomes DB, Lee K, Santos SG, Sousa A, Silva EA, Mooney DJ, Granja PL, Barrias CC (2014) Injectable MMP-sensitive alginate hydrogels as hMSC delivery systems. Biomacromolecules 15: 380-390.

Ford Versypt AN, Pack DW, Braatz RD (2013) Mathematical modeling of drug delivery from autocatalytically degradable PLGA microspheres--a review. J Control Release 165: 29-37.

Fu AS, Thatiparti TR, Saidel GM, von Recum HA (2011) Experimental studies and modeling of drug release from a tunable affinity-based drug delivery platform. Ann Biomed Eng 39: 2466-2475.

Fujisaki J, Tokunaga Y, Takahashi T, Kimura S, Shimojo F, Hata T (1997) Osteotropic drug delivery system (ODDS) based on bisphosphonic prodrug. V. Biological disposition and targeting characteristics of osteotropic estradiol. Biol Pharm Bull 20: 1183-1187.

Fujisaki J, Tokunaga Y, Takahashi T, Shimojo F, Kimura S, Hata T (1998) Osteotropic drug delivery system (ODDS) based on bisphosphonic prodrug. I.v. effects of osteotropic estradiol on bone mineral density and uterine weight in ovariectomized rats. J Drug Target 5: 129-138.
Gabizon A, Catane R, Uziely B, Kaufman B, Safra T, Cohen R, Martin F, Huang A, Barenholz Y (1994) Prolonged circulation time and enhanced accumulation in malignant exudates of doxorubicin encapsulated in polyethylene-glycol coated liposomes. Cancer Res 54: 987-992.

Gao G, Schilling AF, Yonezawa T, Wang J, Dai G, Cui X (2014) Bioactive nanoparticles stimulate bone tissue formation in bioprinted three-dimensional scaffold and human mesenchymal stem cells. Biotechnol J 9: 13041311.

Gao Y, Luo E, Hu J, Xue J, Zhu S, Li J (2009) Effect of combined local treatment with zoledronic acid and basic fibroblast growth factor on implant fixation in ovariectomized rats. Bone 44: 225-232.

Garbern JC, Hoffman AS, Stayton PS (2010) Injectable $\mathrm{pH}$ - and temperature-responsive poly(Nisopropylacrylamide-co-propylacrylic acid) copolymers for delivery of angiogenic growth factors. Biomacromolecules 11: $1833-1839$.

Garcia-Fuentes M, Torres D, Alonso MJ (2005) New surface-modified lipid nanoparticles as delivery vehicles for salmon calcitonin. Int J Pharm 296: 122-132.

Gaudière F, Morin-Grognet S, Bidault L, Lembré P, Pauthe E, Vannier JP, Atmani H, Ladam G, Labat B (2014) Genipin-cross-linked layer-by-layer assemblies: biocompatible microenvironments to direct bone cell fate. Biomacromolecules 15: 1602-1611.

Gellynck K, Shah R, Parkar M, Young A, Buxton P, Brett P (2013) Small molecule stimulation enhances bone regeneration but not titanium implant osseointegration. Bone, 57: 405-412.

Geng Y, Dalhaimer P, Cai S, Tsai R, Tewari M, Minko T, Discher DE (2007) Shape effects of filaments versus spherical particles in flow and drug delivery. Nat Nanotechnol 2: 249-255.

Gil L, Han Y, Opas EE, Rodan GA, Ruel R, Seedor JG, Tyler PC, Young RN (1999) Prostaglandin E2bisphosphonate conjugates: potential agents for treatment of osteoporosis. Bioorg Med Chem 7: 901-919.

Gittens SA, Bansal G, Zernicke RF, Uludag H (2005) Designing proteins for bone targeting. Adv Drug Deliv Rev 57: 1011-1036.

Graham DY (2002) What the gastroenterologist should know about the gastrointestinal safety profiles of bisphosphonates. Dig Dis Sci 47: 1665-1678.

Grassi M, Grassi G (2005) Mathematical modelling and controlled drug delivery: matrix systems. Curr Drug Deliv 2: 97-116.

Gu W, Wu C, Chen J, Xiao Y (2013) Nanotechnology in the targeted drug delivery for bone diseases and bone regeneration. Int J Nanomedicine 8: 2305-2317.

Guillemot F, Souquet A, Catros S, Guillotin B, Lopez J, Faucon M, Pippenger B, Bareille R, Rémy M, Bellance S, Chabassier P, Fricain JC, Amédée J (2010) Highthroughput laser printing of cells and biomaterials for tissue engineering. Acta Biomater 6: 2494-2500.

Guo L, Ma E, Zhao H, Long Y, Zheng C, Duan M (2011) Preliminary evaluation of a novel oral delivery system for rhPTH1-34: in vitro and in vivo. Int $\mathrm{J}$ Pharm 420: 172-179. 
Guo X, Liao J, Park H, Saraf A, Raphael RM, Tabata Y, Kasper FK, Mikos AG (2010) Effects of TGF-beta3 and preculture period of osteogenic cells on the chondrogenic differentiation of rabbit marrow mesenchymal stem cells encapsulated in a bilayered hydrogel composite. Acta Biomater 6: 2920-2931.

Guo X, Park H, Liu G, Liu W, Cao Y, Tabata Y, Kasper FK, Mikos AG (2009) In vitro generation of an osteochondral construct using injectable hydrogel composites encapsulating rabbit marrow mesenchymal stem cells. Biomaterials 30: 2741-2752.

Gupta V, Hwang BH, Lee J, Anselmo AC, Doshi N, Mitragotri S (2013) Mucoadhesive intestinal devices for oral delivery of salmon calcitonin. J Control Release 172: 753-762.

Harris TJ, Green JJ, Fung PW, Langer R, Anderson DG, Bhatia SN (2010) Tissue-specific gene delivery via nanoparticle coating. Biomaterials 31: 998-1006.

He C, Kim SW, Lee DS (2008) In situ gelling stimulisensitive block copolymer hydrogels for drug delivery. J Control Release 127: 189-207.

Helbling IM, Luna JA, Cabrera MI (2011) Mathematical modeling of drug delivery from torus-shaped single-layer devices. J Control Release 149: 258-263.

Herberg S, Kondrikova G, Periyasamy-Thandavan S, Howie RN, Elsalanty ME, Weiss L, Campbell P, Hill WD, Cray JJ (2014) Inkjet-based biopatterning of SDF-1beta augments BMP-2-induced repair of critical size calvarial bone defects in mice. Bone 67: 95-103.

Herczegh P, Buxton TB, McPherson JC 3rd, Kovács-Kulyassa A, Brewer PD, Sztaricskai F, Stroebel GG, Plowman KM, Farcasiu D, Hartmann JF (2002) Osteoadsorptive bisphosphonate derivatives of fluoroquinolone antibacterials. J Med Chem 45: 23382341.

Higuchi T (1961) Rate of release of medicaments from ointment bases containing drugs in suspension. J Pharm Sci 50: 874-875.

Hirabayashi H, Fujisaki J (2003) Bone-specific drug delivery systems: approaches via chemical modification of bone-seeking agents. Clin Pharmacokinet 42: 1319-1330.

Hirabayashi H, Sawamoto T, Fujisaki J, Tokunaga Y, Kimura S, Hata T (2001a) Relationship between physicochemical and osteotropic properties of bisphosphonic derivatives: rational design for osteotropic drug delivery system (ODDS). Pharm Res 18: 646-651.

Hirabayashi H, Takahashi T, Fujisaki J, Masunaga T, Sato S, Hiroi J, Tokunaga Y, Kimura S, Hata T (2001b) Bone-specific delivery and sustained release of diclofenac, a non-steroidal anti-inflammatory drug, via bisphosphonic prodrug based on the Osteotropic Drug Delivery System (ODDS). J Control Release 70: 183-191.

Hochdorffer K, Abu Ajaj K, Schafer-Obodozie C, Kratz F (2012) Development of novel bisphosphonate prodrugs of doxorubicin for targeting bone metastases that are cleaved $\mathrm{pH}$ dependently or by cathepsin B: synthesis, cleavage properties, and binding properties to hydroxyapatite as well as bone matrix. J Med Chem 55: $7502-7515$.

Holt J, Hertzberg B, Weinhold P, Storm W, Schoenfisch M, Dahners L (2011) Decreasing bacterial colonization of external fixation pins through nitric oxide release coatings. J Orthop Trauma 25: 432-437.

Hong JY, Kang SW, Kim JW, Suh SW, Ko YJ, Park JH (2014) Optimal condition of heparin-conjugated fibrin with bone morphogenetic protein-2 for spinal fusion in a rabbit model. Cytotherapy 16: 1441-1448.

Hosain F, Spencer RP, Couthon HM, Sturtz GL (1996) Targeted delivery of antineoplastic agent to bone: biodistribution studies of technetium-99m-labeled gembisphosphonate conjugate of methotrexate. J Nucl Med 37: 105-107.

Howlett CR, Dickson M, Sheridan AK (1984) The fine structure of the proximal growth plate of the avian tibia: vascular supply. J Anat 139 (Pt 1): 115-132.

Hu F, Wang C, Guo S, Sun W, Mi D, Gao Y, Zhang J, Zhu T, Yang S (2011) deltaEF1 promotes osteolytic metastasis of MDA-MB-231 breast cancer cells by regulating MMP-1 expression. Biochim Biophys Acta 1809: 200-210.

Hu Y, Cai K, Luo Z, Jandt KD (2010) Layer-by-layer assembly of beta-estradiol loaded mesoporous silica nanoparticles on titanium substrates and its implication for bone homeostasis. Adv Mater 22: 4146-4150.

Ignjatovic NL, Ninkov P, Sabetrasekh R, Uskokovic DP (2010) A novel nano drug delivery system based on tigecycline-loaded calciumphosphate coated with poly-DLlactide-co-glycolide. J Mater Sci Mater Med 21: 231-239.

Ishibe T, Goto T, Kodama T, Miyazaki T, Kobayashi S, Takahashi T (2009) Bone formation on apatite-coated titanium with incorporated BMP-2/heparin in vivo. Oral Surg Oral Med Oral Pathol Oral Radiol Endod 108: 867875 .

Isikli C, Hasirci V, Hasirci N (2012) Development of porous chitosan-gelatin/hydroxyapatite composite scaffolds for hard tissue-engineering applications. J Tissue Eng Regen Med, 6: 135-143.

Ito T, Takemasa M, Makino K, Otsuka M (2013) Preparation of calcium phosphate nanocapsules including simvastatin/deoxycholic acid assembly, and their therapeutic effect in osteoporosis model mice. J Pharm Pharmacol 65: 494-502.

Jeong B, Kim SW, Bae YH (2002) Thermosensitive sol-gel reversible hydrogels. Adv Drug Deliv Rev 54: $37-$ 51.

Zhang J, Zhao S, Zhu M, Zhu Y, Zhang Y, Liu Z, Zhang C (2014) 3D-printed magnetic Fe3O4/MBG/PCL composite scaffolds with multifunctionality of bone regeneration, local anticancer drug delivery andhyperthermia. J Mater Chem B 2: 7583-7595.

Jindong Z, Hai T, Junchao G, Bo W, Li B, Qiang WB (2010) Evaluation of a novel osteoporotic drug delivery system in vitro: alendronate-loaded calcium phosphate cement. Orthopedics 33: doi: 10.3928/0147744720100625-15.

Kanczler JM, Ginty PJ, White L, Clarke NM, Howdle SM, Shakesheff KM, Oreffo RO (2010) The effect of the delivery of vascular endothelial growth factor and bone morphogenic protein-2 to osteoprogenitor cell populations on bone formation. Biomaterials 31: 1242-1250.

Kawashima Y, Yamamoto H, Takeuchi H, Kuno Y (2000) Mucoadhesive DL-lactide/glycolide copolymer 
nanospheres coated with chitosan to improve oral delivery of elcatonin. Pharm Dev Technol 5: 77-85.

Kempen DH, Lu L, Heijink A, Hefferan TE, Creemers LB, Maran A, Yaszemski MJ, Dhert WJ (2009) Effect of local sequential VEGF and BMP-2 delivery on ectopic and orthotopic bone regeneration. Biomaterials 30: 2816-2825.

Kim HK, Shim WS, Kim SE, Lee KH, Kang E, Kim JH, Kim K, Kwon IC, Lee DS (2009) Injectable in situ-forming $\mathrm{pH} /$ thermo-sensitive hydrogel for bone tissue engineering. Tissue Eng Part A 15: 923-933.

Kim J, Kim IS, Cho TH, Kim HC, Yoon SJ, Choi J, Park Y, Sun K, Hwang SJ (2010) In vivo evaluation of MMP sensitive high-molecular weight HA-based hydrogels for bone tissue engineering. J Biomed Mater Res A 95: 673 681.

Kim J, Kim IS, Cho TH, Lee KB, Hwang SJ, Tae G, Noh I, Lee SH, Park Y, Sun K (2007) Bone regeneration using hyaluronic acid-based hydrogel with bone morphogenic protein-2 and human mesenchymal stem cells. Biomaterials 28: 1830-1837.

Kim MS, Kim SK, Kim SH, Hyun H, Khang G, Lee HB (2006) In vivo osteogenic differentiation of rat bone marrow stromal cells in thermosensitive MPEG-PCL diblock copolymer gels. Tissue Eng 12: 2863-2873.

Kim WU, Lee WK, Ryoo JW, Kim SH, Kim J, Youn J, Min SY, Bae EY, Hwang SY, Park SH, Cho CS, Park JS, Kim HY (2002) Suppression of collagen-induced arthritis by single administration of poly(lactic-co-glycolic acid) nanoparticles entrapping type II collagen: a novel treatment strategy for induction of oral tolerance. Arthritis Rheum 46: 1109-1120.

Kimura Y, Miyazaki N, Hayashi N, Otsuru S, Tamai K, Kaneda Y, Tabata Y (2010) Controlled release of bone morphogenetic protein-2 enhances recruitment of osteogenic progenitor cells for de novo generation of bone tissue. Tissue Eng Part A 16: 1263-1270.

Klenner T, Valenzuela-Paz P, Keppler BK, Angres G, Scherf HR, Wingen F, Amelung F, Schmähl D (1990a) Cisplatin-linked phosphonates in the treatment of the transplantable osteosarcoma in vitro and in vivo. Cancer Treat Rev 17: 253-259.

Klenner T, Wingen F, Keppler B, Valenzuela-Paz P, Amelung F, Schmähl D (1990b) Therapeutic efficacy of two different cytostatic-linked phosphonates in combination with razoxane in the transplantable osteosarcoma of the rat. Clin Exp Metastasis 8: 345-359.

Klibanov AL, Maruyama K, Torchilin VP, Huang L (1990) Amphipathic polyethyleneglycols effectively prolong the circulation time of liposomes. FEBS Lett 268: 235-237.

Kolambkar YM, Dupont KM, Boerckel JD, Huebsch N, Mooney DJ, Hutmacher DW, Guldberg RE (2011) An alginate-based hybrid system for growth factor delivery in the functional repair of large bone defects. Biomaterials 32: $65-74$.

Komaki H, Tanaka T, Chazono M, Kikuchi T (2006) Repair of segmental bone defects in rabbit tibiae using a complex of beta-tricalcium phosphate, type I collagen, and fibroblast growth factor-2. Biomaterials 27: 5118-5126.

Korsmeyer RW, Lustig SR, Peppas NA (1986a) Solute and penetrant diffusion in swellable polymers. I.
Mathematical modeling. Journal of Polymer Science Part B: Polymer Physics 24: 395-408.

Korsmeyer RW, Von Meerwall E, Peppas NA (1986b) Solute and penetrant diffusion in swellable polymers. II. Verification of theoretical models. Journal of Polymer Science Part B: Polymer Physics 24: 409-434.

Kowalczyk R, Harris PW, Brimble MA, Callon KE, Watson M, Cornish J (2012) Synthesis and evaluation of disulfide bond mimetics of amylin-(1-8) as agents to treat osteoporosis. Bioorg Med Chem 20: 2661-2668.

Kunjukunju S, Roy A, Ramanathan M, Lee B, Candiello JE, Kumta PN (2013) A layer-by-layer approach to natural polymer-derived bioactive coatings on magnesium alloys. Acta Biomater 9: 8690-8703.

Kurkuri MD, Aminabhavi TM (2004) Poly(vinyl alcohol) and poly(acrylic acid) sequential interpenetrating network $\mathrm{pH}$-sensitive microspheres for the delivery of diclofenac sodium to the intestine. J Control Release 96: 9-20.

Kurtoglu YE, Navath RS, Wang B, Kannan S, Romero R, Kannan RM (2009) Poly(amidoamine) dendrimer-drug conjugates with disulfide linkages for intracellular drug delivery. Biomaterials 30: 2112-2121.

Lamprecht A, Yamamoto H, Takeuchi H, Kawashima Y (2004) pH-sensitive microsphere delivery increases oral bioavailability of calcitonin. J Control Release 98: 1-9.

Lauzon MA, Bergeron E, Marcos B, Faucheux N (2012) Bone repair: new developments in growth factor delivery systems and their mathematical modeling. $\mathrm{J}$ Control Release 162: 502-520.

Lauzon MA, Marcos B, Faucheux N (2014) Effect of initial pBMP-9 loading and collagen concentration on the kinetics of peptide release and a mathematical model of the delivery system. J Control Release 182: 73-82.

Lazzarato L, Rolando B, Lolli ML, Tron GC, Fruttero R, Gasco A, Deleide G, Guenther HL (2005) Synthesis of NO-donor bisphosphonates and their in-vitro action on bone resorption. J Med Chem 48: 1322-1329.

Leane MM, Nankervis R, Smith A, Illum L (2004) Use of the ninhydrin assay to measure the release of chitosan from oral solid dosage forms. Int J Pharm 271: 241-249.

Lee JH, Park JH, El-Fiqi A, Kim JH, Yun YR, Jang JH, Han CM, Lee EJ, Kim HW (2014) Biointerface control of electrospun fiber scaffolds for bone regeneration: engineered protein link to mineralized surface. Acta Biomater 10: 2750-2761.

Lee K, Silva EA, Mooney DJ (2011) Growth factor delivery-based tissue engineering: general approaches and a review of recent developments. J R Soc Interface 8: 153-170.

Lee WK, Park JY, Jung S, Yang CW, Kim WU, Kim HY, Park JH, Park JS (2005) Preparation and characterization of biodegradable nanoparticles entrapping immunodominant peptide conjugated with PEG for oral tolerance induction. J Control Release 105: 77-88.

Li H, Ge Y, Zhang P, Wu L, Chen S (2012) The effect of layer-by-layer chitosan-hyaluronic acid coating on graftto-bone healing of a poly(ethylene terephthalate) artificial ligament. J Biomater Sci Polym Ed 23: 425-438.

Li X, Shi J, Zhu Y, Shen W, Li H, Liang J, Gao J (2007a) A template route to the preparation of mesoporous 
amorphous calcium silicate with high in vitro bone-forming bioactivity. J Biomed Mater Res B Appl Biomater 83: 431439.

Li X, Wei J, Aifantis KE, Fan Y, Feng Q, Cui FZ, Watari F (2016) Current investigations into magnetic nanoparticles for biomedical applications. J Biomed Mater Res A 104: 1285-1296.

Li XS, Li WQ, Wang WB (2007b) Using targeted magnetic arsenic trioxide nanoparticles for osteosarcoma treatment. Cancer Biother Radiopharm 22: 772-778.

Lin CC, Anseth KS (2009) PEG hydrogels for the controlled release of biomolecules in regenerative medicine. Pharm Res 26: 631-643.

Lin CC, Metters AT (2006) Hydrogels in controlled release formulations: network design and mathematical modeling. Adv Drug Deliv Rev 58: 1379-1408.

Link DP, van den Dolder J, van den Beucken JJ, Wolke JG, Mikos AG, Jansen JA (2008) Bone response and mechanical strength of rabbit femoral defects filled with injectable $\mathrm{CaP}$ cements containing TGF-ss 1 loaded gelatin microparticles. Biomaterials 29: 675-682.

Liu Y, Ding X, Li J, Luo Z, Hu Y, Liu J, Dai L, Zhou J, Hou C, Cai K (2015) Enzyme responsive drug delivery system based on mesoporous silica nanoparticles for tumor therapy in vivo. Nanotechnology 26: 145102.

Low SA, Kopecek J (2012) Targeting polymer therapeutics to bone. Adv Drug Deliv Rev 64: 1189-1204.

Lu HD, Zhao HQ, Wang K, Lv LL (2011) Novel hyaluronic acid-chitosan nanoparticles as non-viral gene delivery vectors targeting osteoarthritis. Int J Pharm 420: 358-365.

Lu Y, Sun W, Gu Z (2014) Stimuli-responsive nanomaterials for therapeutic protein delivery. J Control Release 194C: 1-19.

Luhmann T, Germershaus O, Groll J, Meinel L (2012) Bone targeting for the treatment of osteoporosis. J Control Release 161: 198-213.

Lutolf MP, Lauer-Fields JL, Schmoekel HG, Metters AT, Weber FE, Fields GB, Hubbell JA (2003) Synthetic matrix metalloproteinase-sensitive hydrogels for the conduction of tissue regeneration: engineering cellinvasion characteristics. Proc Natl Acad Sci U S A 100: 5413-5418.

Maeda H (2010) Tumor-selective delivery of macromolecular drugs via the EPR effect: background and future prospects. Bioconjug Chem 21: 797-802.

Maeda H, Bharate GY, Daruwalla J (2009) Polymeric drugs for efficient tumor-targeted drug delivery based on EPR-effect. Eur J Pharm Biopharm 71: 409-419.

Maeda Y, Hojo H, Shimohata N, Choi S, Yamamoto K, Takato T, Chung UI, Ohba S (2013) Bone healing by sterilizable calcium phosphate tetrapods eluting osteogenic molecules. Biomaterials 34: 5530-5537.

Makarov C, Cohen V, Raz-Pasteur A, Gotman I (2014) In vitro elution of vancomycin from biodegradable osteoconductive calcium phosphate-polycaprolactone composite beads for treatment of osteomyelitis. Eur J Pharm Sci 62: 49-56.

Manaka T, Suzuki A, Takayama K, Imai Y, Nakamura H, Takaoka K (2011) Local delivery of siRNA using a biodegradable polymer application to enhance BMPinduced bone formation. Biomaterials 32: 9642-9648.

Manitz R, Lucht W, Strehmel K, Weiner R, Neubert $\mathrm{R}$ (1998) On mathematical modeling of dermal and transdermal drug delivery. J Pharm Sci 87: 873-879.

Mann AP, Tanaka T, Somasunderam A, Liu X, Gorenstein DG, Ferrari M (2011) E-selectin-targeted porous silicon particle for nanoparticle delivery to the bone marrow. Adv Mater 23: H278-H282.

Matsumura Y, Maeda H (1986) A new concept for macromolecular therapeutics in cancer chemotherapy: mechanism of tumoritropic accumulation of proteins and the antitumor agent smancs. Cancer Res 46: 6387-6392.

McClean S, Prosser E, Meehan E, O’Malley D, Clarke N, Ramtoola Z, Brayden D (1998) Binding and uptake of biodegradable poly-DL-lactide micro- and nanoparticles in intestinal epithelia. Eur J Pharm Sci 6: 153-163.

Mendes LS, Saska S, Martines MA, Marchetto R (2013) Nanostructured materials based on mesoporous silica and mesoporous silica/apatite as osteogenic growth peptide carriers. Mater Sci Eng C Mater Biol Appl 33: 4427-4434.

Merkel TJ, Jones SW, Herlihy KP, Kersey FR, Shields AR, Napier M, Luft JC, Wu H, Zamboni WC, Wang AZ, Bear JE, DeSimone JM (2011) Using mechanobiological mimicry of red blood cells to extend circulation times of hydrogel microparticles. Proc Natl Acad Sci U S A 108: 586-591.

Mi HY, Palumbo S, Jing X, Turng LS, Li WJ, Peng XF (2014) Thermoplastic polyurethane/hydroxyapatite electrospun scaffolds for bone tissue engineering: effects of polymer properties and particle size. J Biomed Mater Res B Appl Biomater 102: 1434-1444.

Miao T, Rao KS, Spees JL, Oldinski RA (2014) Osteogenic differentiation of human mesenchymal stem cells through alginate-graft-poly(ethylene glycol) microsphere-mediated intracellular growth factor delivery. J Control Release 192: 57-66.

Miller K, Eldar-Boock A, Polyak D, Segal E, Benayoun L, Shaked Y, Satchi-Fainaro R (2011) Antiangiogenic antitumor activity of HPMA copolymer-paclitaxelalendronate conjugate on breast cancer bone metastasis mouse model. Mol Pharm 8: 1052-1062.

Miller K, Erez R, Segal E, Shabat D, Satchi-Fainaro R (2009) Targeting bone metastases with a bispecific anticancer and antiangiogenic polymer-alendronate-taxane conjugate. Angew Chem Int Ed Engl 48: 2949-2954.

Miller SC, Pan H, Wang D, Bowman BM, Kopeckova P, Kopecek J (2008) Feasibility of using a bonetargeted, macromolecular delivery system coupled with prostaglandin $\mathrm{E}(1)$ to promote bone formation in aged, estrogen-deficient rats. Pharm Res 25: 2889-2895.

Milleret V, Simona BR, Lienemann PS, Voros J, Ehrbar M (2014) Electrochemical control of the enzymatic polymerization of PEG hydrogels: formation of spatially controlled biological microenvironments. Adv Healthc Mater 3: 508-514.

Min J, Braatz RD, Hammond PT (2014) Tunable staged release of therapeutics from layer-by-layer coatings with clay interlayer barrier. Biomaterials 35: 2507-2517. 
Moghimi SM, Hunter AC, Murray JC (2001) Longcirculating and target-specific nanoparticles: theory to practice. Pharmacol Rev 53: 283-318.

Moghimi SM, Illum L, Davis SS (1990) Physiopathological and physicochemical considerations in targeting of colloids and drug carriers to the bone marrow. Crit Rev Ther Drug Carrier Syst 7: 187-209.

Monjo M, Rubert M, Wohlfahrt JC, Ronold HJ, Ellingsen JE, Lyngstadaas SP (2010) In vivo performance of absorbable collagen sponges with rosuvastatin in critical-size cortical bone defects. Acta Biomater 6: 1405 1412.

Moore L, Gatica M, Kim H, Osawa E, Ho D (2013) Multi-protein delivery by nanodiamonds promotes bone formation. J Dent Res 92: 976-981.

Morgen M, Tung D, Boras B, Miller W, Malfait AM, Tortorella M (2013) Nanoparticles for improved local retention after intra-articular injection into the knee joint. Pharm Res 30: 257-268.

Mosley GL, Yamanishi CD, Kamei DT (2013) Mathematical modeling of vesicle drug delivery systems 1: vesicle formation and stability along with drug loading and release. J Lab Autom 18: 34-45.

Mullen L, Adams G, Foster J, Vessillier S, Köster M, Hauser H, Layward L, Gould D, Chernajovsky Y (2014) A comparative study of matrix metalloproteinase and aggrecanase mediated release of latent cytokines at arthritic joints. Ann Rheum Dis 73: 1728-1736.

Murphy MB, Hartgerink JD, Goepferich A, Mikos AG (2007) Synthesis and in vitro hydroxyapatite binding of peptides conjugated to calcium-binding moieties. Biomacromolecules 8: 2237-2243.

Na K, Kim SW, Sun BK, Woo DG, Yang HN, Chung HM, Park KH (2007) Osteogenic differentiation of rabbit mesenchymal stem cells in thermo-reversible hydrogel constructs containing hydroxyapatite and bone morphogenic protein-2 (BMP-2). Biomaterials 28: 2631 2637.

Nandagiri VK, Gentile P, Chiono V, Tonda-Turo C, Matsiko A, Ramtoola Z, Montevecchi FM, Ciardelli G (2011) Incorporation of PLGA nanoparticles into porous chitosan-gelatin scaffolds: influence on the physical properties and cell behavior. J Mech Behav Biomed Mater 4: 1318-1327.

Naniwa T, Maeda T, Mizoshita T, Hayami Y, Watanabe M, Banno S, Ito R (2008) Alendronate-induced esophagitis: possible pathogenic role of hypersensitivity to alendronate. Intern Med 47: 2083-2085.

Narayanan D, Anitha A, Jayakumar R, Chennazhi KP (2014) PTH 1-34 loaded thiolated chitosan nanoparticles for osteoporosis: oral bioavailability and anabolic effect on primary osteoblast cells. J Biomed Nanotechnol 10: 166-178.

Narayanan D, Anitha A, Jayakumar R, Nair SV, Chennazhi KP (2012) Synthesis, characterization and preliminary in vitro evaluation of PTH 1-34 loaded chitosan nanoparticles for osteoporosis. J Biomed Nanotechnol 8: 98-106.

Nichols SP, Storm WL, Koh A, Schoenfisch MH (2012) Local delivery of nitric oxide: targeted delivery of therapeutics to bone and connective tissues. Adv Drug Deliv Rev 64: 1177-1188.

Ogbomo SM, Shi W, Wagh NK, Zhou Z, Brusnahan SK, Garrison JC (2013) 177Lu-labeled HPMA copolymers utilizing cathepsin B and S cleavable linkers: synthesis, characterization and preliminary in vivo investigation in a pancreatic cancer model. Nuclear medicine and biology 40: 606-617.

Oh JM, Park CB, Choy JH (2011) Intracellular drug delivery of layered double hydroxide nanoparticles. J Nanosci Nanotechnol 11: 1632-1635.

Ohashi S, Kubo T, Ikeda T, Arai Y, Takahashi K, Hirasawa Y, Takigawa M, Satoh E, Imanishi J, Mazda O (2001) Cationic polymer-mediated genetic transduction into cultured human chondrosarcoma-derived HCS-2/8 cells. J Orthop Sci 6: 75-81.

Otsuka M, Matsuda Y, Baig AA, Chhettry A, Higuchi WI (2000) Calcium-level responsive controlled drug delivery from implant dosage forms to treat osteoporosis in an animal model. Adv Drug Deliv Rev 42: 249-258.

Pan H, Sima M, Kopeckova P, Wu K, Gao S, Liu J, Wang D, Miller SC, Kopecek J (2008) Biodistribution and pharmacokinetic studies of bone-targeting N-(2hydroxypropyl)methacrylamide copolymer-alendronate conjugates. Mol Pharm 5: 548-558.

Papahadjopoulos D, Allen TM, Gabizon A, Mayhew E, Matthay K, Huang SK, Lee KD, Woodle MC, Lasic DD, Redemann C (1991) Sterically stabilized liposomes: improvements in pharmacokinetics and antitumor therapeutic efficacy. Proc Natl Acad Sci U S A 88: 1146011464.

Park H, Temenoff JS, Tabata Y, Caplan AI, Raphael RM, Jansen JA, Mikos AG (2009) Effect of dual growth factor delivery on chondrogenic differentiation of rabbit marrow mesenchymal stem cells encapsulated in injectable hydrogel composites. J Biomed Mater Res A 88: 889-897.

Park YJ, Nah SH, Lee JY, Jeong JM, Chung JK, Lee MC, Yang VC, Lee SJ (2003) Surface-modified poly(lactide-co-glycolide) nanospheres for targeted bone imaging with enhanced labeling and delivery of radioisotope. J Biomed Mater Res A 67: 751-760.

Patel ZS, Young S, Tabata Y, Jansen JA, Wong ME, Mikos AG (2008) Dual delivery of an angiogenic and an osteogenic growth factor for bone regeneration in a critical size defect model. Bone 43: 931-940.

Patois E, Osorio-da Cruz S, Tille JC, Walpoth B, Gurny R, Jordan O (2009) Novel thermosensitive chitosan hydrogels: in vivo evaluation. J Biomed Mater Res A 91: 324-330.

Peng KT, Chen CF, Chu IM, Li YM, Hsu WH, Hsu RW, Chang PJ (2010a) Treatment of osteomyelitis with teicoplanin-encapsulated biodegradable thermosensitive hydrogel nanoparticles. Biomaterials 31: 5227-5236.

Peng KT, Hsu WH, Hsu RW (2010b) Improved antibiotic impregnated cement prosthesis for treating deep hip infection: a novel design using hip compression screw. J Arthroplasty 25: 1304-1306.

Peppas NA (1985) Analysis of Fickian and non-Fickian drug release from polymers. Pharm Acta Helv 60: 110-111.

Peppas NA (2013) Historical perspective on advanced drug delivery: how engineering design and mathematical 
modeling helped the field mature. Adv Drug Deliv Rev 65: 5-9.

Petit A, Sandker M, Muller B, Meyboom R, van Midwoud P, Bruin P, Redout EM, Versluijs-Helder M, van der Lest CH, Buwalda SJ, de Leede LG, Vermonden T, Kok RJ, Weinans H, Hennink WE (2014) Release behavior and intra-articular biocompatibility of celecoxib-loaded acetylcapped PCLA-PEG-PCLA thermogels. Biomaterials 35: 7919-7928.

Petrie Aronin CE, Shin SJ, Naden KB, Rios PD Jr, Sefcik LS, Zawodny SR, Bagayoko ND, Cui Q, Khan Y, Botchwey EA (2010) The enhancement of bone allograft incorporation by the local delivery of the sphingosine 1-phosphate receptor targeted drug FTY720. Biomaterials 31: 6417-6424.

Petros RA, DeSimone JM (2010) Strategies in the design of nanoparticles for therapeutic applications. Nat Rev Drug Discov 9: 615-627.

Pignatello R, Cenni E, Micieli D, Fotia C, Salerno M, Granchi D, Avnet S, Sarpietro MG, Castelli F, Baldini N (2009) A novel biomaterial for osteotropic drug nanocarriers: synthesis and biocompatibility evaluation of a PLGA-ALE conjugate. Nanomedicine (Lond) 4: 161-175.

Pistone A, Iannazzo D, Panseri S, Montesi M, Tampieri A, Galvagno S (2014) Hydroxyapatite-magnetite-MWCNT nanocomposite as a biocompatible multifunctional drug delivery system for bone tissue engineering. Nanotechnology 25: 425701.

Porter CJ, Moghimi SM, Illum L, Davis SS (1992) The polyoxyethylene/polyoxypropylene block co-polymer poloxamer-407 selectively redirects intravenously injected microspheres to sinusoidal endothelial cells of rabbit bone marrow. FEBS Lett 305: 62-66.

Poth N, Seiffart V, Gross G, Menzel H, Dempwolf W (2015) Biodegradable chitosan nanoparticle coatings on titanium for the delivery of BMP-2. Biomolecules 5: 3-19.

Purcell BP, Lobb D, Charati MB, Dorsey SM, Wade RJ, Zellars KN, Doviak H, Pettaway S, Logdon CB, Shuman JA, Freels PD, Gorman JH $3^{\text {rd }}$, Gorman RC, Spinale FG, Burdick JA (2014) Injectable and bioresponsive hydrogels for on-demand matrix metalloproteinase inhibition. Nat Mater 13: 653-661.

Qi Y, Zhao T, Yan W, Xu K, Shi Z, Wang J (2013) Mesenchymal stem cell sheet transplantation combined with locally released simvastatin enhances bone formation in a rat tibia osteotomy model. Cytotherapy 15: 44-56.

Qiu Y, Park K (2001) Environment-sensitive hydrogels for drug delivery. Adv Drug Deliv Rev 53: 321-339.

Raiche AT, Puleo DA (2001) Triphasic release model for multilayered gelatin coatings that can recreate growth factor profiles during wound healing. J Drug Target 9: 449-460.

Ramanlal Chaudhari K, Kumar A, Megraj Khandelwal VK, Ukawala M, Manjappa AS, Mishra AK, Monkkonen J, Ramachandra Murthy RS (2012) Bone metastasis targeting: a novel approach to reach bone using Zoledronate anchored PLGA nanoparticle as carrier system loaded with Docetaxel. J Control Release 158: 470-478.

Ramier J, Bouderlique T, Stoilova O, Manolova N, Rashkov I, Langlois V, Renard E, Albanese P, Grande D (2014) Biocomposite scaffolds based on electrospun poly(3-hydroxybutyrate) nanofibers and electrosprayed hydroxyapatite nanoparticles for bone tissue engineering applications. Mater Sci Eng C Mater Biol Appl 38: 161169.

Ray K (2012) Therapy: Silencing inhibitors of bone formation. Nat Rev Rheumatol 8: 122.

Reinholz MM, Zinnen SP, Dueck AC, Dingli D, Reinholz GG, Jonart LA, Kitzmann KA, Bruzek AK, Negron V, Abdalla AK, Arendt BK, Croatt AJ, SanchezPerez L, Sebesta DP, Lönnberg H, Yoneda T, Nath KA, Jelinek DF, Russell SJ, Ingle JN, Spelsberg TC, Dixon HB, Karpeisky A, Lingle WL (2010) A promising approach for treatment of tumor-induced bone diseases: utilizing bisphosphonate derivatives of nucleoside antimetabolites. Bone 47: 12-22.

Ren J, Blackwood KA, Doustgani A, Poh PP, Steck R, Stevens MM, Woodruff MA (2014) Melt-electrospun polycaprolactone strontium-substituted bioactive glass scaffolds for bone regeneration. J Biomed Mater Res A 102: $3140-3153$.

Richardson TP, Peters MC, Ennett AB, Mooney DJ (2001) Polymeric system for dual growth factor delivery. Nat Biotechnol 19: 1029-1034.

Ross RD, Roeder RK (2011) Binding affinity of surface functionalized gold nanoparticles to hydroxyapatite. J Biomed Mater Res A 99: 58-66.

Rossouw JE, Anderson GL, Prentice RL, LaCroix AZ, Kooperberg C, Stefanick ML, Jackson RD, Beresford SA, Howald BV, Johnson KC, Kotchen JM, Ockene J, Writing Group for the Women's Health Initiative Investigators (2002) Risks and benefits of estrogen plus progestin in healthy postmenopausal women: principal results From the Women's Health Initiative randomized controlled trial. JAMA 288: 321-333.

Rubert M, Pullisaar H, Gomez-Florit M, Ramis JM, Tiainen H, Haugen HJ, Lyngstadaas SP, Monjo M (2013) Effect of $\mathrm{TiO}_{2}$ scaffolds coated with alginate hydrogel containing a proline-rich peptide on osteoblast growth and differentiation in vitro. J Biomed Mater Res A 101: 1768-1777.

Ruppel ME, Miller LM, Burr DB (2008) The effect of the microscopic and nanoscale structure on bone fragility. Osteoporos Int 19: 1251-1265.

Sackett CK, Narasimhan B (2011) Mathematical modeling of polymer erosion: consequences for drug delivery. Int J Pharm 418: 104-114.

Sahoo S, Ang LT, Goh JC, Toh SL (2010) Growth factor delivery through electrospun nanofibers in scaffolds for tissue engineering applications. J Biomed Mater Res A 93: $1539-1550$.

Salerno M, Cenni E, Fotia C, Avnet S, Granchi D, Castelli F, Micieli D, Pignatello R, Capulli M, Rucci N, Angelucci A, Del Fattore A, Teti A, Zini N, Giunti A, Baldini N (2010) Bone-targeted doxorubicin-loaded nanoparticles as a tool for the treatment of skeletal metastases. Curr Cancer Drug Targets 10: 649-659.

Sang Yoo H, Gwan Park T (2004) Biodegradable nanoparticles containing protein-fatty acid complexes for oral delivery of salmon calcitonin. J Pharm Sci 93: 488495. 
Santo VE, Gomes ME, Mano JF, Reis RL (2013) Controlled release strategies for bone, cartilage, and osteochondral engineering--Part II: challenges on the evolution from single to multiple bioactive factor delivery. Tissue Eng Part B Rev 19: 327-352.

Sarin H (2010) Physiologic upper limits of pore size of different blood capillary types and another perspective on the dual pore theory of microvascular permeability. $\mathrm{J}$ Angiogenes Res 2: 14.

Satarkar NS, Zach Hilt J (2008) Hydrogel nanocomposites as remote-controlled biomaterials. Acta Biomater 4: 11-16.

Schettini DA, Ribeiro RR, Demicheli C, Rocha OG, Melo MN, Michalick MS, Frézard F (2006) Improved targeting of antimony to the bone marrow of dogs using liposomes of reduced size. Int J Pharm 315: 140-147.

Schipper NG, Romeijn SG, Verhoef J, Merkus FW (1994) Hypocalcemic effect of salmon calcitonin following single and repeated nasal and intravenous administration in young rabbits. Calcif Tissue Int 54: 50-55.

Schluep T, Hwang J, Cheng J, Heidel JD, Bartlett DW, Hollister B, Davis ME (2006) Preclinical efficacy of the camptothecin-polymer conjugate IT-101 in multiple cancer models. Clin Cancer Res 12: 1606-1614.

Segal E, Pan H, Benayoun L, Kopecková P, Shaked Y, Kopecek J, Satchi-Fainaro R (2011) Enhanced antitumor activity and safety profile of targeted nano-scaled HPMA copolymer-alendronate-TNP-470 conjugate in the treatment of bone malignances. Biomaterials 32: 44504463.

Segal E, Pan H, Ofek P, Udagawa T, Kopecková P, Kopecek J, Satchi-Fainaro R (2009) Targeting angiogenesis-dependent calcified neoplasms using combined polymer therapeutics. PloS One 4:e5233.

Sensenig R, Sapir Y, MacDonald C, Cohen S, Polyak B (2012) Magnetic nanoparticle-based approaches to locally target therapy and enhance tissue regeneration in vivo. Nanomedicine (Lond) 7: 1425-1442.

Shah NJ, Hyder MN, Moskowitz JS, Quadir MA, Morton SW, Seeherman HJ, Padera RF, Spector M, Hammond PT (2013) Surface-mediated bone tissue morphogenesis from tunable nanolayered implant coatings. Sci Transl Med 5: 191ra183.

Shaikh RP, Pillay V, Choonara YE, du Toit LC, Ndesendo VM, Bawa P, Cooppan S (2010) A review of multi-responsive membranous systems for rate-modulated drug delivery. AAPS PharmSciTech 11:441-459.

Shen SC, Ng WK, Chia LS, Dong YC, Tan RB (2013) Applications of mesoporous materials as excipients for innovative drug delivery and formulation. Curr Pharm Des 19: 6270-6289.

Shi CG, Zhang Y, Yuan W (2015) Efficacy of bisphosphonates on bone mineral density and fracture rate in patients with osteogenesis imperfecta: a systematic review and meta-analysis. Am J Ther 23: e894-904. doi: 10.1097/MJT.0000000000000236.

Shuid AN, Ibrahim N, Mohd Amin MC, Mohamed IN (2013) Drug delivery systems for prevention and treatment of osteoporotic fracture. Curr Drug Targets 14: 1558-1564.
Siepmann J, Gopferich A (2001) Mathematical modeling of bioerodible, polymeric drug delivery systems. Adv Drug Deliv Rev 48: 229-247.

Siepmann J, Peppas NA (2001a) Mathematical modeling of controlled drug delivery. Adv Drug Deliv Rev 48: 137-138.

Siepmann J, Peppas NA (2001b) Modeling of drug release from delivery systems based on hydroxypropyl methylcellulose (HPMC). Adv Drug Deliv Rev 48: 139157.

Siepmann J, Peppas NA (2011) Higuchi equation: derivation, applications, use and misuse. Int J Pharm 418: 6-12.

Siepmann J, Siepmann F (2008) Mathematical modeling of drug delivery. Int J Pharm 364: 328-343.

Siepmann J, Siepmann F (2012) Modeling of diffusion controlled drug delivery. J Control Release 161: 351-362.

Siepmann J, Siepmann F (2013) Mathematical modeling of drug dissolution. Int J Pharm 453: 12-24.

Simmons CA, Alsberg E, Hsiong S, Kim WJ, Mooney DJ (2004) Dual growth factor delivery and controlled scaffold degradation enhance in vivo bone formation by transplanted bone marrow stromal cells. Bone 35: 562-569.

Sipkins DA, Wei X, Wu JW, Runnels JM, Côte D, Means TK, Luster AD, Scadden DT, Lin CP (2005) In vivo imaging of specialized bone marrow endothelial microdomains for tumour engraftment. Nature 435: 969973.

Sood N, Bhardwaj A, Mehta S, Mehta A (2014) Stimuli-responsive hydrogels in drug delivery and tissue engineering. Drug Deliv 23: 758-780.

Sou K, Goins B, Leland MM, Tsuchida E, Phillips WT (2010) Bone marrow-targeted liposomal carriers: a feasibility study in nonhuman primates. Nanomedicine (Lond) 5: 41-49.

Sou K, Goins B, Oyajobi BO, Travi BL, Phillips WT (2011) Bone marrow-targeted liposomal carriers. Expert Opin Drug Deliv 8: 317-328.

Srouji S, Ben-David D, Lotan R, Livne E, Avrahami R, Zussman E (2011) Slow-release human recombinant bone morphogenetic protein-2 embedded within electrospun scaffolds for regeneration of bone defect: in vitro and in vivo evaluation. Tissue Eng Part A 17: 269-277.

Stadelmann VA, Gauthier O, Terrier A, Bouler JM, Pioletti DP (2008) Implants delivering bisphosphonate locally increase periprosthetic bone density in an osteoporotic sheep model. A pilot study. Eur Cell Mater 16: 10-16.

Stirling HF, Darling JA, Barr DG (1991) Plasma cyclic AMP response to intravenous parathyroid hormone in pseudohypoparathyroidism. Acta Paediatr Scand 80: 333338 .

Such GK, Yan Y, Johnston AP, Gunawan ST, Caruso F (2015) Interfacing materials science and biology for drug carrier design. Adv Mater 27: 2278-2297.

Sun K, Wang J, Zhang J, Hua M, Liu C, Chen T (2011) Dextran-g-PEI nanoparticles as a carrier for co-delivery of adriamycin and plasmid into osteosarcoma cells. Int J Biol Macromol 49: 173-180.

Susa M, Iyer AK, Ryu K, Hornicek FJ, Mankin H, Amiji MM, Duan Z (2009) Doxorubicin loaded Polymeric 
Nanoparticulate Delivery System to overcome drug resistance in osteosarcoma. BMC Cancer 9: 399.

Swami A, Reagan MR, Basto P, Mishima Y, Kamaly N, Glavey S, Zhang S, Moschetta M, Seevaratnam D, Zhang Y, Liu J, Memarzadeh M, Wu J, Manier S, Shi J, Bertrand N, Lu ZN, Nagano K, Baron R, Sacco A, Roccaro AM, Farokhzad OC, Ghobrial IM (2014) Engineered nanomedicine for myeloma and bone microenvironment targeting. Proc Natl Acad Sci USA 111: 10287-10292.

Tai IC, Fu YC, Wang CK, Chang JK, Ho ML (2013) Local delivery of controlled-release simvastatin/ PLGA/HAp microspheres enhances bone repair. Int $\mathrm{J}$ Nanomedicine 8: 3895-3904.

Takahashi-Nishioka T, Yokogawa K, Tomatsu S, Nomura M, Kobayashi S, Miyamoto K (2008) Targeted drug delivery to bone: pharmacokinetic and pharmacological properties of acidic oligopeptide-tagged drugs. Curr Drug Discov Technol 5: 39-48.

Takaishi H, Kimura T, Dalal S, Okada Y, D’Armiento J (2008) Joint diseases and matrix metalloproteinases: a role for MMP-13. Curr Pharm Biotechnol 9: 47-54.

Takeuchi H, Matsui Y, Yamamoto H, Kawashima Y (2003) Mucoadhesive properties of carbopol or chitosancoated liposomes and their effectiveness in the oral administration of calcitonin to rats. J Control Release 86: 235-242.

Tam CS, Heersche JN, Murray TM, Parsons JA (1982) Parathyroid hormone stimulates the bone apposition rate independently of its resorptive action: differential effects of intermittent and continuous administration. Endocrinology 110: 506-512.

Tao L, Hu W, Liu Y, Huang G, Sumer BD, Gao J (2011) Shape-specific polymeric nanomedicine: emerging opportunities and challenges. Exp Biol Med (Maywood) 236: 20-29.

Tashjian AH JR, Goltzman D (2008) On the interpretation of rat carcinogenicity studies for human PTH(1-34) and human PTH(1-84). J Bone Miner Res 23: 803-811.

Tautzenberger A, Kovtun A, Ignatius A (2012) Nanoparticles and their potential for application in bone. Int J Nanomedicine 7: 4545-4557.

Tetteh G, Khan AS, Delaine-Smith RM, Reilly GC, Rehman IU (2014) Electrospun polyurethane/ hydroxyapatite bioactive Scaffolds for bone tissue engineering: the role of solvent and hydroxyapatite particles. J Mech Behav Biomed Mater 39: 95-110.

Thanyaphoo S, Kaewsrichan J (2012) Synthesis and evaluation of novel glass ceramics as drug delivery systems in osteomyelitis. J Pharm Sci 101: 2870-2882.

Torchilin V (2011) Tumor delivery of macromolecular drugs based on the EPR effect. Adv Drug Deliv Rev 63: 131-135.

Torchilin VP (2005) Lipid-core micelles for targeted drug delivery. Curr Drug Deliv 2: 319-327.

Torchilin VP (2014) Multifunctional, stimuli-sensitive nanoparticulate systems for drug delivery. Nat Rev Drug Discov 13: 813-827.

Toub N, Bertrand JR, Tamaddon A, Elhamess H, Hillaireau H, Maksimenko A, Maccario J, Malvy C, Fattal E, Couvreur P (2006) Efficacy of siRNA nanocapsules targeted against the EWS-Fli1 oncogene in Ewing sarcoma. Pharm Res 23: 892-900.

Travlos GS (2006) Normal structure, function, and histology of the bone marrow. Toxicol Pathol 34: 548-565.

Truong NP, Gu W, Prasadam I, Jia Z, Crawford R, Xiao Y, Monteiro MJ (2013) An influenza virus-inspired polymer system for the timed release of siRNA. Nat Commun 4: 1902.

Tsavaris N, Kopterides P, Kosmas C, Vadiaka M, Dimitrakopoulos A, Scopelitis H, Tenta R, Vaiopoulos G, Koufos C (2006) Analgesic activity of high-dose intravenous calcitonin in cancer patients with bone metastases. Oncol Rep 16: 871-875.

Tsiridis E, Upadhyay N, Giannoudis P (2007) Molecular aspects of fracture healing: which are the important molecules? Injury 38 Suppl 1:S11-S25.

Tsushima N, Yabuki M, Harada H, Katsumata T, Kanamaru H, Nakatsuka I, Yamamoto M, Nakatsuka M (2000) Tissue distribution and pharmacological potential of SM-16896, a novel oestrogen-bisphosphonate hybrid compound. J Pharm Pharmacol 52: 27-37.

Tzafriri AR, Lerner EI, Flashner-Barak M, Hinchcliffe M, Ratner E, Parnas H (2005) Mathematical modeling and optimization of drug delivery from intratumorally injected microspheres. Clin Cancer Res 11: 826-834.

Uludag H (2002) Bisphosphonates as a foundation of drug delivery to bone. Curr Pharm Des 8: 1929-1944.

Uskokovic V, Desai TA (2013) Phase composition control of calcium phosphate nanoparticles for tunable drug delivery kinetics and treatment of osteomyelitis. II. Antibacterial and osteoblastic response. J Biomed Mater Res A 101: 1427-1436.

Uskokovic V, Desai TA (2014) In vitro analysis of nanoparticulate hydroxyapatite/chitosan composites as potential drug delivery platforms for the sustained release of antibiotics in the treatment of osteomyelitis. J Pharm Sci 103: 567-579.

Usui Y, Aoki K, Narita N, Murakami N, Nakamura I, Nakamura K, Ishigaki N, Yamazaki H, Horiuchi H, Kato H, Taruta S, Kim YA, Endo M, Saito N (2008) Carbon nanotubes with high bone-tissue compatibility and boneformation acceleration effects. Small 4: 240-246.

Vallet-Regi M, Izquierdo-Barba I, Colilla M (2012) Structure and functionalization of mesoporous bioceramics for bone tissue regeneration and local drug delivery. Philos Trans A Math Phys Eng Sci 370: 1400-1421.

Velghe C, Rosiaux Y, Marchaud D, Siepmann J, Siepmann F (2014) In silico simulation of niacin release from lipid tablets: theoretical predictions and independent experiments. J Control Release 175: 63-71.

Vennila V, Madhu V, Rajesh R, Ealla KK, Velidandla SR, Santoshi S (2014) Tetracycline-induced discoloration of deciduous teeth: case series. J Int Oral Health 6: 115-119.

Verron E, Gauthier O, Janvier P, Pilet P, Lesoeur $\mathrm{J}$, Bujoli B, Guicheux J, Bouler JM (2010) In vivo bone augmentation in an osteoporotic environment using bisphosphonate-loaded calcium deficient apatite. Biomaterials 31: 7776-7784.

Vo TN, Kasper FK, Mikos AG (2012) Strategies for controlled delivery of growth factors and cells for bone regeneration. Adv Drug Deliv Rev 64: 1292-1309. 
Wang D, Miller SC, Kopeckova P, Kopecek J (2005) Bone-targeting macromolecular therapeutics. Adv Drug Deliv Rev 57: 1049-1076.

Wang D, Sima M, Mosley RL, Davda JP, Tietze N, Miller SC, Gwilt PR, Kopecková P, Kopecek J (2006) Pharmacokinetic and biodistribution studies of a bone-targeting drug delivery system based on N-(2hydroxypropyl)methacrylamide copolymers. Mol Pharm 3: 717-725.

Wang M, Hu H, Sun Y, Qiu L, Zhang J, Guan G, Zhao X, Qiao M, Cheng L, Cheng L, Chen D (2013) A pHsensitive gene delivery system based on folic acid-PEGchitosan - PAMAM-plasmid DNA complexes for cancer cell targeting. Biomaterials 34: 10120-10132.

Wang X, Wenk E, Zhang X, Meinel L, VunjakNovakovic G, Kaplan DL (2009) Growth factor gradients via microsphere delivery in biopolymer scaffolds for osteochondral tissue engineering. J Control Release 134: 81-90.

Wang Y, Grainger DW (2012) RNA therapeutics targeting osteoclast-mediated excessive bone resorption. Adv Drug Deliv Rev 64: 1341-1357.

Wang Y, Tran KK, Shen H, Grainger DW (2012) Selective local delivery of RANK siRNA to bone phagocytes using bone augmentation biomaterials. Biomaterials 33: 8540-8547.

Watanabe A, Yoneyama S, Nakajima M, Sato N, Takao-Kawabata R, Isogai Y, Sakurai-Tanikawa A, Higuchi K, Shimoi A, Yamatoya H, Yoshida K, Kohira T (2012) Osteosarcoma in Sprague-Dawley rats after long-term treatment with teriparatide (human parathyroid hormone (1-34)). J Toxicol Sci 37: 617-629.

Wei G, Jin Q, Giannobile WV, Ma PX (2007) The enhancement of osteogenesis by nano-fibrous scaffolds incorporating rhBMP-7 nanospheres. Biomaterials 28: 2087-2096.

Werle M, Samhaber A, Bernkop-Schnurch A (2006) Degradation of teriparatide by gastro-intestinal proteolytic enzymes. J Drug Target 14: 109-115.

Wilson AN, Guiseppi-Elie A (2013) Bioresponsive hydrogels. Adv Healthc Mater 2: 520-532.

Wingen F, Pool BL, Klein P, Klenner T, Schmahl D (1988) Anticancer activity of bisphosphonic acids in methylnitrosourea-induced mammary carcinoma of the rat--benefit of combining bisphosphonates with cytostatic agents. Invest New Drugs 6: 155-167.

Wu C, Chang J (2012) Mesoporous bioactive glasses: structure characteristics, drug/growth factor delivery and bone regeneration application. Interface Focus 2: 292-306.

Wu C, Chang J (2014) Multifunctional mesoporous bioactive glasses for effective delivery of therapeutic ions and drug/growth factors. J Control Release 193: 282-295.

Wu C, Fan W, Chang J, Xiao Y (2013) Mesoporous bioactive glass scaffolds for efficient delivery of vascular endothelial growth factor. J Biomater Appl 28: 367-374.

Wu C, Miron R, Sculean A, Kaskel S, Doert T, Schulze R, Zhang Y (2011) Proliferation, differentiation and gene expression of osteoblasts in boron-containing associated with dexamethasone deliver from mesoporous bioactive glass scaffolds. Biomaterials 32: 7068-7078.
Wu Z, Tang T, Guo H, Tang S, Niu Y, Zhang J, Zhang W, Ma R, Su J, Liu C, Wei J (2014) In vitro degradability, bioactivity and cell responses to mesoporous magnesium silicate for the induction of bone regeneration. Colloids Surf B Biointerfaces 120: 38-46.

$\mathrm{Xu} \mathrm{HH}$, Weir MD, Simon CG (2008) Injectable and strong nano-apatite scaffolds for cell/growth factor delivery and bone regeneration. Dent Mater 24: 1212-1222.

Xu Z, Liu S, Kang Y, Wang M (2015) Glutathione- and $\mathrm{pH}$-responsive nonporous silica prodrug nanoparticles for controlled release and cancer therapy. Nanoscale 7: 58595868.

Yamada M, Tsukimura N, Ikeda T, Sugita Y, Att W, Kojima N, Kubo K, Ueno T, Sakurai K, Ogawa T (2013) $\mathrm{N}$-acetyl cysteine as an osteogenesis-enhancing molecule for bone regeneration. Biomaterials 34: 6147-6156.

Yamamoto M, Takahashi Y, Tabata Y (2006) Enhanced bone regeneration at a segmental bone defect by controlled release of bone morphogenetic protein-2 from a biodegradable hydrogel. Tissue Eng 12: 1305-1311.

Yan X, Huang X, Yu C, Deng H, Wang Y, Zhang Z, Qiao S, Lu G, Zhao D (2006) The in-vitro bioactivity of mesoporous bioactive glasses. Biomaterials 27: 3396-3403.

Yan X, Yu C, Zhou X, Tang J, Zhao D (2004) Highly ordered mesoporous bioactive glasses with superior in vitro bone-forming bioactivities. Angew Chem Int Ed Engl 43: 5980-5984.

Yang GL, He FM, Yang XF, Wang XX, Zhao SF (2009) In vivo evaluation of bone-bonding ability of RGD-coated porous implant using layer-by-layer electrostatic selfassembly. J Biomed Mater Res A 90: 175-185.

Yang HS, La WG, Bhang SH, Jeon JY, Lee JH, Kim BS (2010) Heparin-conjugated fibrin as an injectable system for sustained delivery of bone morphogenetic protein-2. Tissue Eng Part A 16: 1225-1233.

Yang XN, Zeng JC, Song YC, Zhang H, Pei FX (2014) Targeted antiosteosarcoma methotrexate-bisphosphonate conjugate induces apoptosis of osteosarcoma cells in vitro. Eur Rev Med Pharmacol Sci 18: 2116-2123.

Yao Y, Wang C, Varshney RR, Wang DA (2009) Antisense makes sense in engineered regenerative medicine. Pharm Res 26: 263-275.

Yasmeen S, Lo MK, Bajracharya S, Roldo M (2014) Injectable scaffolds for bone regeneration. Langmuir 30: 12977-12985.

Yewle JN, Puleo DA, Bachas LG (2013) Bifunctional bisphosphonates for delivering PTH (1-34) to bone mineral with enhanced bioactivity. Biomaterials 34: 3141-3149.

Yilgor P, Hasirci N, Hasirci V (2010) Sequential BMP2/BMP-7 delivery from polyester nanocapsules. J Biomed Mater Res A 93: 528-536.

Yoshii T, Hafeman AE, Esparza JM, Okawa A, Gutierrez G, Guelcher SA (2014) Local injection of lovastatin in biodegradable polyurethane scaffolds enhances bone regeneration in a critical-sized segmental defect in rat femora. J Tissue Eng Regen Med 8: 589-595.

Young S, Patel ZS, Kretlow JD, Murphy MB, Mountziaris PM, Baggett LS, Ueda H, Tabata Y, Jansen JA, Wong M, Mikos AG (2009) Dose effect of dual delivery of vascular endothelial growth factor and bone morphogenetic 
protein-2 on bone regeneration in a rat critical-size defect model. Tissue Eng Part A 15: 2347-2362.

Young S, Wong M, Tabata Y, Mikos AG (2005) Gelatin as a delivery vehicle for the controlled release of bioactive molecules. J Control Release 109: 256-274.

Zhang G, Guo B, Wu H, Tang T, Zhang L, He Y, Yang Z, Pan X, Chow H, To K, Li Y, Li D, Wang X, Wang Y, Lee K, Hou Z, Dong N, Li G, Leung K, Hung L, He F, Zhang L, Qin L (2012a) A delivery system targeting bone formation surfaces to facilitate RNAi-based anabolic therapy. Nat Med 18: 307-314.

Zhang N, Shen Y, Li X, Cai S, Liu M (2012b) Synthesis and characterization of thermo- and $\mathrm{pH}$-sensitive poly(vinyl alcohol)/poly(N, N-diethylacrylamide-co-itaconic acid) semi-IPN hydrogels. Biomed Mater 7: 035014.

Zhang S, Gangal G, Uludag H (2007) 'Magic bullets' for bone diseases: progress in rational design of boneseeking medicinal agents. Chem Soc Rev 36: 507-531.

Zhang X, Kovtun A, Mendoza-Palomares C, OuladAbdelghani M, Fioretti F, Rinckenbach S, Mainard D, Epple M, Benkirane-Jessel N (2010) SiRNA-loaded multishell nanoparticles incorporated into a multilayered film as a reservoir for gene silencing. Biomaterials 31: 6013-6018.

Zhang X, Yu C, Xushi, Zhang C, Tang T, Dai K (2006) Direct chitosan-mediated gene delivery to the rabbit knee joints in vitro and in vivo. Biochem Biophys Res Commun 341: 202-208.

Zheng LZ, Cao HJ, Chen SH, Tang T, Fu WM, Huang L, Chow DH, Wang YX, Griffith JF, He W, Zhou H, Zhao DW, Zhang G, Wang XL, Qin L (2015) Blockage of Src by Specific siRNA as a Novel Therapeutic Strategy to Prevent Destructive Repair in Steroid-Associated Osteonecrosis in Rabbits. J Bone Miner Res 30: 2044-2057.

Zhou P, Cheng X, Xia Y, Wang P, Zou K, Xu S, Du J (2014) Organic/inorganic composite membranes based on poly(L-Lactic-co-Glycolic Acid) and mesoporous silica for effective bone tissue engineering. ACS Appl Mater Interfaces 6: 20895-208903.

\section{Discussion with Reviewers}

Christine Hartmann: What are the current technical limitations to nanotechnology?

Authors: Nanotechnology has revolutionised scientific research and is presently the major driving force behind industrial and biomedical discovery. Its fields of applications are virtually unlimited and encompass enormous socioeconomic gains. Still, also potentially great putative risks must be foreseen and addressed by the scientific and governmental community. Risk assessment and risk management programs must be fostered and the exploitation of matter and processes at the nanoscale must be regulated. Currently, research on nanomaterials safety is a very hot topic and the object of significant efforts and investment as exemplified by being one of the main foci of the EU's research and innovation funding programme, Horizon 2020.

In the biological and biomedical field, a major technical hurdle is the absence of imaging equipment with detection limits within the nano range that allow a precise assessment of nanoparticles biodistribution and metabolism in live organisms.

Current bioimaging analysis require the accumulation of nanoparticles and most investigation techniques resort to ex vivo evaluations that are very limiting not only in the course of research but most particularly when considering the translation from animal to human applications.

Although in the last decades tremendous technological advances have been put to use in the field of nanotechnology, the understanding and control of matter and processes at the nanoscale is still far from being achieved. The lack of adequate mathematical models that describe the properties of matter at the nanoscale level is presently an important limitation for the development of novel applications that exploit the particularity of nano-materials, devices and systems in the benefit of society.

Christine Hartmann: Where do you see the greatest potential to further improve nanotechnology as a delivery system to bone?

Authors: In recent decades, the application of nanotechnology into the biomedical field has allowed an exceptional improvement of diagnostic tools and clinical treatments offering new means to overcome many of the classical drug delivery limitations, such as poor solubility, high toxicity, lack of specificity, degradation and short half-life after administration.

In bone regeneration, nanoparticle technology showed very promising results for delivery of therapeutic agents (proteins, drugs, genes) and for the design of scaffolds with improved biocompatibility and mechanical properties. Still, there is yet a long way to go before nanotechnology as a delivery system to bone becomes a clinical practice and assumes a leading role in bone regeneration therapies. Current bone-targeting delivery systems distribute drugs to the whole skeleton and not to the specific functional cells in bone, which reduces the treatment efficiency and bears the risk of toxic effects on non-targeted cells. Future efforts in the design of drug delivery systems to bone must address with precision the particularities of the bone regeneration process, such as the fact that it involves a large number of different cell types and the participation of many intracellular and extracellular signalling pathways, that interact in a space and temporal-dependent manner. A better understanding of the cellular and molecular interaction between nanostructures and the specific cell types (such as mesenchymal stem cells, osteoblasts, osteocytes, osteoclasts and even inflammatory cells) involved in bone regeneration in a time- and space- dependent manner, as well as the understanding of the underlying biochemical pathways being activated in different disease states, offers exciting new possibilities to the improvement of the targeting specificity and efficacy of delivery systems to bone and can provide a new paradigm for the treatment of bone diseases.

Editor's Note: Scientific Editor in charge of the paper: Christine Hartmann. 